\title{
Retelling Copyright: The Contributions of the Restatement of Copyright Law
}

\author{
Jeanne C. Fromer ${ }^{\dagger} \&$ Jessica Silbey ${ }^{\dagger \dagger}$
}

Introduction 341

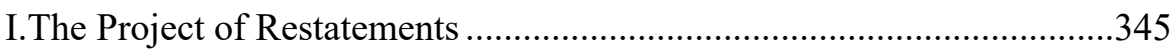

II.The Inevitability of Retelling the Law .................................................349

A. The Restatement's Precursors: Stare Decisis and Treatises ...350

B. The Restatement as Unremarkable Legal Interpretation ..........354

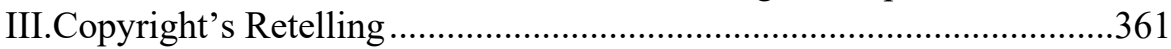

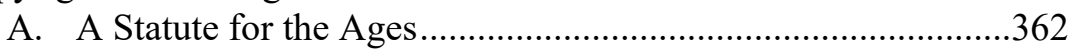

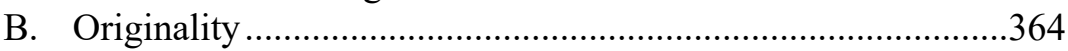

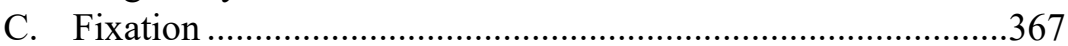

D. Categories of Copyrightable Subject Matter.............................370

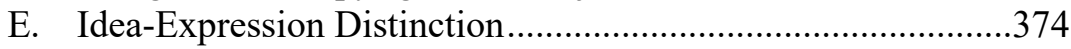

F. Authorship and Ownership ...................................................377

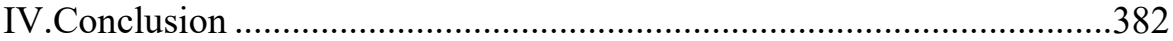

\section{INTRODUCTION}

Since the American Law Institute (ALI) launched in the early twentieth century, its mission has been "the clarification and simplification of the law and its better adaptation to social needs ... [and] to secure the better administration of justice." A principal way it has pursued that mission has been through its Restatements of

$\dagger \quad$ Professor of Law, New York University School of Law; Faculty Co-Director, Engelberg Center on Innovation Law \& Policy; Adviser, Restatement of Law, Copyright; Member, American Law Institute.

$\pitchfork$ Professor of Law, Boston University School of Law. A substantial part of the work for this Article was completed while Professor Silbey was still on the faculty at Northeastern School of Law. Thanks to Dean James Hackney of Northeastern University School of Law for research leave and support to work on this project. The authors also thank Arnaud Ajdler, Shyam Balganesh, Barton Beebe, Rochelle Dreyfuss, Christopher Morten, and Christopher Sprigman, and participants in a colloquium at NYU School of Law for their clarifying takes. Thanks to Zachary Shufro for extraordinary research assistance.

1. How the Institute Works, AM. LAW INST., https://perma.cc/925F-SX5F (last visited Jan. 23, 2021).

(C) 2021 Fromer \& Silbey. This is an open access article distributed under the terms of the Creative Commons Attribution-NonCommercial-NoDerivatives License, which permits noncommercial use, distribution, and reproduction, provided the original author and source are credited, and the article is not changed. 
Law project. $^{2}$ By their nature, Restatements of Law reflect tensions between what it means to "restate" and reform the law. As the ALI has grown and the legal profession has evolved with social and political changes, the organization has ensured professionalism and the incorporation of diverse views to manage this tension at the heart of its Restatement projects.

Against this backdrop, the ALI announced in 2014 that it would begin a Restatement of Copyright Law project in 2015 and we, as copyright lawyers and scholars, applaud that decision. ${ }^{3}$ The ALI specified that the project

will focus on the generally applicable parts of copyright law, including the subject matter of copyright; the scope of the exclusive rights granted by copyright; copyright 'formalities'; the rules governing ownership and transfer of copyrights; the duration of copyright; the standard for copyright infringement; rules regarding the circumvention of copyright protection systems; defenses to copyright infringement, including the first sale limitation and fair use; and remedies, including actual and statutory damages, attorney['s] fees, preliminary and permanent injunctive relief; and criminal penalties. ${ }^{4}$

Since this announcement, the Restatement of Copyright Law project has been a lightning rod for controversy. The Authors Guild, the Association of American Publishers, the Motion Picture Association of America, the Recording Industry Association of America, and fourteen other organizations wrote to the ALI expressing the worry that "the conception of the project and the recent appointment of its Reporter indicate a significant risk that it would be used as a vehicle not to restate the law of copyright, but, rather, to rewrite it to benefit a particular viewpoint in the copyright debate." 5 The Acting Register of Copyrights wrote to the ALI that the Restatement project is "misguided" and that "[ $t]$ he need for the Restatement is unclear, as an extensive body of positive copyright law already exists." 6 The Copyright \& Literary Property Committee of the New York City Bar Association prepared a report against the project on the basis that "rather than simply clarifying or restating that law, the draft offers commentary and interpretations beyond the current state of the law that appear intended to shape current and future copyright policy." The head of the National Music Publishers' Association called the project a "sham attempt to undermine hard fought principles of understood law" and urged that " $[\mathrm{t}]$ his thinly-veiled attempt to subvert the law and undermine creators . . must

2. See infra Part I.

3. The American Law Institute Announces Four New Projects, AM. LAW INST. (Nov. 17, 2014), https://perma.cc/E6S5-827N.

4. Id.

5. Letter from Am. Photographic Artists et al. to ALI Officers and Dirs. (Oct. 14, 2015), https://perma.cc/3BS3-M7KS.

6. Letter from Karyn Temple Claggett, Acting Reg. of Copyrights, to ALI President David Levi et al., Re: Council Draft No. 1, Restatement of the Law, Copyright (Jan. 16, 2018), https://perma.cc/ZC67$23 \times 7$.

7. COPYRIGHT \& Literary Prop. COMM., ReCOMMENDATION TO REJECT THE AMERICAN LAW institute's Proposal to Create a Restatement of Law, N.Y.C. Bar Ass'N (Jan. 16, 2018), https://perma.cc/GG89-DXYV. 
be stopped." 8 And just last year, five members of Congress criticized the project, noting that "laws created through federal statute, including federal copyright law, are ill-suited for treatment in a Restatement because the law is clearly articulated by Congress in both the statute and the legislative history." 9 They elaborated that "any Restatement or other treatise relied on by courts that attempts to diminish the importance of the statutory text or legislative history relating to that text would warrant concern." 10 Furthermore, they asserted that "[c]ourts should rely on that statutory text and legislative history, not Restatements that attempt to replace the statutory language and legislative history established by Congress with novel interpretations." 11

Some commentators have expressed skepticism that these critiques are honest. Instead, they suspect that they are a smoke screen for critics' fears that a Restatement of Copyright Law would provide an understanding of copyright law that would undermine the ability of content creators and others to shape the law in their favor. ${ }^{12}$ Whatever the truth, for purposes of this Article, we accept the critics at their word. And we think their criticisms of the Restatement of Copyright Law project are exaggerated and mistaken. As we contend herein, the act of restating in the manner that is the ALI's signature form is consistent with the practice of law generally, which inevitably involves acts of legal exposition and interpretation. ${ }^{13}$ It is not inherently partisan but a professional practice in which all lawyers are taught to engage. Stating the law, saying what it means, and then applying it in a particular context are what lawyers and judges do all the time. In this way, restating - or "retelling" - the law is both normal and inevitable. A restatement of law is another way of saying what the law is.

To be sure, copyright law is grounded in a federal statute, while the more common ALI Restatements of the Law, such as the Restatements of Contracts and Torts, are

8. Chris Cooke, Music Industry Hits Out at American Law Institute's 'Restatement' of Copyright Law, COMPLETE MUSIC UPDATE (Oct. 18, 2018), https://perma.cc/YBN5-3MQU.

9. Letter from Sen. Thom Tillis, Rep. Ben Cline, Rep. Theodore E. Deutch, Rep. Martha Roby, and Rep. Harley Rouda to ALI Dir. Richard L. Revesz (Dec. 3, 2019), https://perma.cc/LWE9-3YYZ [hereinafter Letter from Sen. Tillis et al.].

10. Id.

11. Id.

12. See Brian L. Frye (@brianlfrye), TwitTER (Dec. 5, 2019, 3:15 PM EST), https://twitter.com/brianlfrye/status/1202683033595400194 ("I find it deeply amusing that the primary objection to the restatement of copyright is that the ALI is insufficiently captured by industry insiders. Quel dommage."); Mark McKenna (@markpmckenna), TwiTTER (Dec. 5, 2019, 1:54 PM EST), https://twitter.com/markpmckenna/status/1202662535033507841 (“[T]hat's why opposition without seeing the drafts seems clearly ideological. The rest of what you say (deep disagreement, etc) doesn't distinguish copyright from other areas, like, say, torts.”); Brandon Butler (@bc_butler), TwITTER (Dec. 5, 2019, 7:38 AM EST), https://twitter.com/bc_butler/status/1202567936034136064 ("The copyright rent-seeker lobby's anxiety over the Restatement should be seen for what it is: an expression of sheer terror that copyright will be authoritatively explained by experts who have never been and will never be on their payroll."); cf. Brandon Butler (@bc_butler), TwITTER (Dec. 9, 2019, 10:12 AM EST), https://twitter.com/bc_butler/status/1204056189643841537 (sarcastically stating that "[w]e can't have a Restatement of Copyright because the professionals at the Copyright Office are the only people we can trust to give an unbiased, expert explanation of-oh").

13. See infra Part II. 
based in common law. ${ }^{14}$ These previous Restatements helped guide interstate practice and coordinate legal development across the fifty states. The 1976 Copyright Act, the principal federal statute governing copyright law, may be a single federal statute for the whole nation, but its development over forty years by courts in thirteen separate circuits through thousands upon thousands of cases has not always been uniform or crystal clear. The 1976 Copyright Act both draws on longstanding common law elucidated by federal courts and uses language indicating Congress intended for courts to continue expounding the common law in essential ways. ${ }^{15}$ Moreover, as Congress intimated when it enacted the 1976 Act, it was enacting a copyright statute for the ages. In four decades, Congress has not returned to revise the central aspects of the law to which the ALI Restatement of Copyright Law now turns its attention. This confirms that it was intended for long-range judicial interpretation subject to complex and diverse doctrinal evolution. For these reasons, we should welcome a carefully crafted Restatement of Copyright Law to help courts and lawyers ascertain the central rules of copyright law as they have evolved over the past forty years.

The provisions at issue in the draft Restatement of Copyright Law on which ALI membership will vote at ALI's upcoming annual meeting are central to copyright doctrine and have been the subject of numerous court decisions over the past several decades of technological and industry change: originality, fixation, categories of copyrightable subject matter, the idea-expression distinction, and authorship and ownership. ${ }^{16}$ This abundance of legal activity on copyright law demonstrates the value to the profession of this project retelling copyright. In contrast to the dramatic criticism of this Restatement project alleging political capture or illegitimate law reform, the draft's provisions are routine and straightforward. They will surprise no one and are almost boring in their adherence to and synthesis of the copyright statute and judicial interpretations of it. Far from being radical or ill-advised, the Restatement of Copyright Law is a reasonable and welcome addition to the work of the ALI.

Part I of this Article situates the current Restatement of Copyright Law in the historical context of other ALI projects, drawing parallels in their purposes, processes, and political tensions. Part II describes the controversy over a "retelling" of copyright law as misguided insofar as it fails to account for the practice of interpretation as part of the practice of law that is constrained by professional standards. Part III describes the analysis and exposition of the provisions of the draft portions of the Restatement of Copyright Law presented to the ALI membership for discussion and vote this year as unremarkable but also beneficial, achieving the ALI's goals of clarification and simplification of the sprawling federal case law interpreting and applying the 1976 Copyright Act.

14. As described in Part I in more detail, not all ALI projects are restatements based in common law, however.

15. See infra Part III.

16. Restatement of the Law, Copyright (Am. L. InSt., Tentative Draft No. 1, Apr. 8, 2020) [hereinafter Restatement Tentative Draft No. 1 (2020)]. 


\section{THE PROJECT OF RESTATEMENTS}

The ALI's history and structure have been described in numerous articles. ${ }^{17}$ Notable among these histories is a debate about whether the ALI's purpose is properly understood as describing the law or proposing reform. As summarized below, this debate began with the ALI's origins. The initial " "pragmatic reformist' drive of [its] founders" remains a critical feature of the ALI and an enduring source of tension. ${ }^{18}$ Other controversies surrounding ALI projects over the course of the twentieth century relate to this tension, and some are simply the product of an evolving and growing membership organization whose structure is intentionally deliberative and democratic. The tensions endemic to democratic institutionscharges of hierarchy and elitism, problems of exclusivity and lack of diversity, and the scope and substance of the public interest - have plagued the ALI over the decades. The Restatement of Copyright Law project may therefore produce similar tensions, but they arise because of the nature of the ALI, not because of the nature of copyright law.

The ALI explains its mission as "the clarification and simplification of the law and its better adaptation to social needs ... [and] to secure the better administration of justice." 19 This mission dates back to 1906, when the idea of the ALI was first proposed, well before it was founded in $1923 .{ }^{20}$ As described in a critical history of the ALI, the ALI originated from a struggle circa 1906 between the American Bar Association (ABA) member lawyers and the American Association of Law Schools (AALS) member law professors. ${ }^{21}$ The disagreement was not over the necessity of an organization devoted to clarifying the sprawling terrain of judicial decisions. That important purpose was understood and accepted. Rather, it was over the nature of law that was to be clarified. Today, we recall this debate as the beginning of the jurisprudential shift from legal formalism to legal realism; but, at the time, the disagreements were personal and described as pitting an "old guard" of "conservative" practitioners against "progressive-minded," "younger men."22

The leader of the "progressive-minded" lawyers was thirty-eight-year-old Roscoe Pound, then dean of University of Nebraska Law School. When Pound gave a speech at an ABA meeting in 1906 criticizing the growing imprecision of legal decisionmaking, he pleaded for law to be more responsive to the evolution of social and economic life. ${ }^{23}$ The growing inconsistencies among legal decisions across the

17. Some notable histories include Alex Elson, The Case for an In-Depth Study of the American Law Institute, 23 LAW \& Soc. INQ. 625 (1998); N.E.H. Hull, Restatement and Reform: A New Perspective on the Origins of the American Law Institute, 8 LAW \& HIST. REV. 55 (1990); see also John P. Frank, The American Law Institute, 1923-1998, 26 HOFSTRA L. REV. 615 (1998).

18. Elson, supra note 17, at 627; see also Alan Schwartz \& Robert Scott, The Political Economy of Private Legislatures, 143 U. PA. L. REV. 595, 597 (1995) (critiquing the ALI and National Conference of Commissioners on Uniform State Laws as private legislatures despite the fact that, according to the authors, politics should not influence either organization).

19. See How the Institute Works, supra note 1.

20. Hull, supra note 17 , at 56

21. Id. at $56-58$.

22. Id. at $57-58$.

23. Id. at $56-57$. 
country were as much a result of legal formalism's rigidity as they were a function of the vast accumulation of cases across diverse populations and rapidly changing circumstances of modern industrialism at the turn of the century. ${ }^{24}$ Pound's speech was ill-received at the ABA, but several law professors in attendance were energized and saw an opportunity "to do something about it in [their] own limited spheres." 25 Accompanying Pound on this mission was John Henry Wigmore (dean of Northwestern Law School), William Draper Lewis (founding dean of the University of Pennsylvania Law School and director of the ALI from its founding to 1947), and George Boke of the University of California at Berkeley. ${ }^{26}$ Their initial plan in 1906 eventually came to fruition after much consternation and compromise in 1923.

The years spanning 1906 to 1923 were full of tensions reflecting the ALI's original and enduring purpose. Though the skirmishes do not need detailed recounting here, in general they concerned the evolving role of law schools in training lawyers for practice or as scholars in jurisprudence and legal history. ${ }^{27}$ Wesley Newcomb Hohfeld of Yale Law School was at the center of this debate. As recounted by one historian, "[t]he essence of [Hohfeld's] plan was the new-found self-importance of the legal academic. ... [He] complained, 'the majority of the universities have ... been content to offer purely professional or vocational courses in law along conventional lines - what is commonly called general jurisprudence being entirely, or almost entirely, ignored." ${ }^{28}$ Hohfeld's idea was that some law schools would provide the research and theory on which better understanding of the law and suggestions for its reform could rely. This proposal led to debates with the AALS that were tinged with, among other things, not-so-subtle classism, racism, and xenophobia that threatened less prestigious law schools and those with night programs aimed at first-generation students with second-class status. ${ }^{29}$ The reform effort to establish a law institute that could improve an understanding of the law and advance the administration of justice reproduced within law schools many of the destructive social and political hierarchies outside the profession and in society at large. ${ }^{30}$

World War I interrupted the debate and, at the war's end, resulted in compromise. The ALI would be independent from law schools; but it would be comprised of members from the legal academy who had time to devote to the project, as well as judges and practicing lawyers who would add professional legitimacy to the project. ${ }^{31}$ The leaders of this compromise were Elihu Root, Secretary of State under Theodore Roosevelt, and Eugene Gilmore, professor of law at University of

24. Id.

25. Id. at 58

26. $I d$.

27. Id. at $70-72$.

28. Id. at 59 .

29. Id. at 63 .

30. Cf. Richard Yeselson, The Return of the 1920s, THE ATLANTIC (Dec. 30, 2015), https://perma.cc/SWC8-NKYF (comparing polarization of the 2010s to that of the 1920s after a period of rapid industrialization, restructuring of labor and professions, and drastic increase in wealth inequality).

31. Hull, supra note 17 , at 72 . 
Wisconsin Law School and president of the AALS. ${ }^{32}$ The story is more complicated and involves an inspiring speech at an annual AALS meeting by then-New York Court of Appeals Judge Benjamin Cardozo, who "persuasively represented the perspective of a working judge [and] the desire by judges themselves for the clarification and reform of the law now contemplated by the law professors." ${ }^{33}$ Ultimately, compromise occurred, and when the ALI was founded in 1923, it had evolved into "an active, independent organization of law professors, lawyers, and judges dedicated to progressive law reform." "34

While the First Restatement project cautiously reflected this compromise with a "dogmatic affirmation" of black letter law, the subsequent Second Restatement project reflected the maturity of ALI's purpose. ${ }^{35}$ It contained more exposition and analysis and was geared more toward elucidating majority and minority views and recommending an optimal path. ${ }^{36}$ Herbert Wechsler, the director of the ALI at midcentury for the Second Restatement project, "took a more active reformist position," asserting "that what courts do in a given situation cannot be divorced from the view of what they ought to do." 37

The ALI's goal all along was "reform," but what that means has evolved. It started as clarification and harmonization by reflecting more everyday and particularized experience instead of adhering to abstract principles. Intermittent skirmishes during the twentieth century over the ALI's elitism and exclusivity, present at its beginning and continuing throughout the century, ignited further debates over the meaning of reform by asking "reform for whom?" By the mid- to late-twentieth century, characteristic controversies concerned special-interest lobbying, member-client conflicts, and political preferences of member factions. ${ }^{38}$ These debates were about, for example: whether ALI lawyer members do in fact "leave their clients at the door" ${ }^{\prime 39}$; whether membership is appropriately intellectually diverse and informed by expertise beyond law (such as in economics and urban policy) ${ }^{40}$; and whether membership was sufficiently representative of the bar as a whole. ${ }^{41}$ Studies of the ALI recount special-interest lobbying of members by specific

\footnotetext{
32. Id. at 74 .

33. Id. at 73 .

34. Id. at 69 .

35. Elson, supra note 17, at 628.

36. Id.; see also Bennet Boskey, The American Law Institute: A Glimpse at Its Future, 12 GREEN BAG 2d, at 255, 257 (2009).

37. Elson, supra note 17, at 628.

38. Id. at 629 .

39. AM LAW INST., COUNCIL R. 9.04 ("To maintain the Institute's reputation for thoughtful, disinterested analysis of legal issues, members are expected to leave client interests at the door. Members should speak and vote on the basis of their personal and professional convictions and experience without regard to client interests or self-interest."); see also Lawrence J. Fox, Leave Your Clients at the Door, 26 HOFSTRA L. REV. 595, 608 (1998) (describing special-interest lobbying of members by insurance company clients with reference to the Restatement of Law Governing Lawyers); Charles W. Wolfram, Bismarck's Sausages and the ALI's Restatements, 26 HOFSTRA L. REV 817, 821-28 (1998) (recounting the same).

40. Elson, supra note 17, at 633

41. Id.
} 
industries (such as insurance), especially with regard to corporate governance, products liability, and the law of lawyers. ${ }^{42}$ These controversies were largely resolved with rule changes clarifying the ALI's mission to serve the public interest, by enlarging its membership to include legal academics with specific expertise, and by reaffirming adherence to professional standards of the independent "lawyer statesman." ${ }^{43}$ To be sure, these standards may weaken as time goes on. ${ }^{44}$ And as the ALI grows in size, while it may be more diverse along relevant qualities (including subject-matter expertise, geography, ethnicity, gender, professional experience, and affiliation), it also may become more unwieldy, generating more contestation and disagreement.

Today, the ALI has over 3,500 members with an elaborate and layered process for drafting, revising, and approving Restatements. ${ }^{45}$ The size and complexity of this process have led critics to ask whether it produces effective collaboration and deliberation. ${ }^{46}$ Others have suggested that the ALI is in essence a private legislature, but without the error correction and accountability mechanisms legislative processes assure. ${ }^{47}$ Both of these criticisms challenge the core mission of the ALI to provide clarifying and accurate legal expertise on which judges and lawyers may rely. But these problems are endemic to any influential and expert organization grounded in principles of diversity and professionalism that continues to grow in size, not to the ALI specifically. And, although it may be true that the ALI is not accountable to its constituents the way legislatures are, there is no reason to believe that the ALI's members - and the Reporters and Advisors doing the lion's share of the drafting work - are not as good (or bad) as legislators at finding facts and collecting empirical data useful for analyzing and expounding the law. Moreover, the transparency of the ALI process and its layers of membership review provide meaningful measures of accountability and create ample information with which to evaluate the merits of the final product on which the ALI's reputation and authority depend. After all, a Restatement is not binding on courts or legislatures. ${ }^{48}$ Its persuasiveness resides in the quality of its procedural layers of review and the rigor, expertise, and professionalism of its members.

The ALI's success over the years has led to its expansion beyond Restatements to the development of Principles and Model Codes. These have included influential projects such as the Uniform Commercial Code, the Model Penal Code, Model Code of Evidence, and less successful ones such as recommendations for improving federal tax and securities law. ${ }^{49}$ These projects are addressed to legislatures and

42. Id. at 626; see also Fox, supra note 39, at 608.

43. Elson, supra note 17, at 630.

44. As one author writes, "[p]rofessionalism has yielded to commercialization and marketing and denigration of public service, akin to some business enterprises." Id. at 631.

45. See How the Institute Works, supra note 1; Elson, supra note 17, at 633-34 (describing the ALI's process).

46. Elson, supra note 17 , at 634

47. Schwartz \& Scott, supra note 18, at 22.

48. Arthur Corbin, The Restatement of the Common Law by the American Law Institute, 15 IowA L. REV. 19, 36, 39 (1929).

49. Boskey, supra note 36, at 258-59; Elson, supra note 17, at 628. 
governmental agencies and take the form of explicit recommendations for statutory language or guiding principles for statutory enactments; ${ }^{50}$ they are not Restatements or expositions of existing cases. In the context of all of these efforts, the Restatement of Copyright Law is but one of many projects aimed at clarifying and explaining the increasingly complex and numerous court decisions, in this case about copyright law, to aid practitioners in its application to particular circumstances. Whether the Restatement of Copyright Law will be widely adopted by practitioners, as have other ALI Restatement projects, remains to be seen. That it should be attempted and that it is within the ALI's mandate is, to us, without a doubt. What then generates controversy about this Restatement project? ${ }^{51}$

\section{THE INEVITABILITY OF RETELLING THE LAW}

The act of restating in the manner that is the ALI's signature form is consistent with the practice of law generally, which inevitably involves acts of legal exposition and interpretation. Stating the law and saying what it means, and then applying it in a particular context, are what lawyers and judges do all the time. In this way, restating - or "retelling"- the law is both normal and inevitable, even though copyright law is based in a federal statute.

To be sure, sometimes restating the law may be difficult and fraught with controversy. For example, typical difficulties of interpretation arise in the context of linguistic ambiguity, distances in time and changes of circumstances, and complex or contradictory historical textual origins. ${ }^{52}$ Who renders the interpretation may also raise concerns of subjectivity and the influence of moral or political standards, as opposed to technical and professional ones. ${ }^{53}$ This was evident in earlier disputes among ALI members about other projects. ${ }^{54}$ These controversies over interpretation are not new in the ALI or in law generally, and lawyers and judges learn to negotiate them as part of law's practice. Like many related disciplines such as history, religion, and literature, law requires interpretation, and the act of engaging in it is part of its authoritative endeavor. ${ }^{55}$ The ALI's Restatement of Copyright Law project is just an extension of what it means to engage in the practice of law.

50. Elson, supra note 17, at 629 (describing the Principles of Corporate Governance Project as stated by Ray Garrett Jr., the first chief reporter of the project); How the Institute Works, supra note 1.

51. See supra text accompanying notes 5-11 (summarizing the controversy over this project).

52. See, e.g., KeIth E. WhitTington, CONSTitutional InTERPRETATION: TeXtUAL MEANing, ORIGINAL INTENT, AND JUDICIAL REVIEW 5-13 (1999) (asking these questions regarding constitutional law).

53. See GUyORA Binder \& Robert WeISBERG, Literary CRiticisms OF LAW 160 (2000) ("Interpretation is objective ... as long as individual interpreters do not interpret as they wish.").

54. Fox, supra note 39, at 608 (discussing accusations of bias and special-interest lobbying in the process of the Restatement of Law Governing Lawyers).

55. Producing and assessing many versions of what the law is or how it should be applied in a particular circumstance is essential to law's legitimacy as an essential socio-political institution. See, e.g., Patricia EWick \& Susan Silbey, The Common Place of LaW: Stories From Everyday Life 1520 (1988) (explaining how the inevitability of contrasting accounts of law's fit and function is essential to its durability). 


\section{A. The Restatement's Precursors: Stare Decisis and Treatises}

Law's persistence in society as a source of order and control requires law's retelling by judges and lawyers and by legally adjacent professionals such as law enforcement officers, human resource professionals, and tax accountants. In other words, law's retelling is central to the rule of law, which is the principle that legal subjects be treated as equals, reasonably, and not arbitrarily. In order to determine if the law as decreed is fair and reliable, it must be restated publicly so legal subjects have the "opportunity to make arguments about the application of legal rules to their circumstances [and] the public at large may observe these reasons and the arguments about them." 56 As Paul Gowder writes:

The heart of this conception of the rule of law is responsiveness to reasons. The ... rule of law treats people with respect, as minimally capable of responding to reasons given them by preexisting rules that govern their behavior, while also restricting those officials who wield coercive power to acting in accordance with those reasons, rather than simply their own wills. Moreover, they directly recruit the capacity of ordinary people to reason about reasons by making the use of state force against them conditional on their having an opportunity to publicly contest and deploy the reasons given by law.... The form of a reason is the opposite of arbitrariness. ... [T] he official who is bound to legal reasons at least has to be able to say something that is comprehensible to the person over whom power is exercised. In doing so, that official treats the other like an adult, and an equal. ${ }^{57}$

Law's public retelling comes in several forms, officially from the state and unofficially through non-state actors. Before considering the Restatement of Copyright Law, we concern ourselves with some of the most common official and unofficial forms - judicial opinions and legal treatises — both of which are precursors to ALI's Restatements of Law.

Judicial opinions need no explanation, except to say that they accomplish through the process of stare decisis the strengthening of the rule of law through redundancy about and feedback on the rules of law themselves.$^{58}$ Understood through the frame of communications theory, Martin Shapiro describes stare decisis as a form of "incremental modes of decision-making" containing "extremely high levels of redundancy in the communications linking the decision-making units." 59 He says further that "the characteristic style of Anglo-American legal discourse persists [as a] ... rather standard and routine solution to the noise problem of a non-hierarchical organization like the courts." ${ }^{\circ 0}$ Restating the law and the process of stare decisis maintain order and authority for the rules within a community of diverse actors.

Relying on similar concepts, the U.S. Supreme Court frequently expounds the importance and centrality of stare decisis to the rule of law. In milestone cases facing a call to overrule past decisions, the Supreme Court explains that cases must be

\footnotetext{
56. Paul Gowder, The Rule of LaW IN THE REAL World 7 (2016).

57. Id. at 8 .

58. Martin Shapiro, Toward a Theory of 'Stare Decisis', 1 J. LEgal StUD. 125, 127, 129 (1972).

59. Id. at 127,132

60. Id. at 134 .
} 
decided in light of previous ones to avoid arbitrariness and that compelling reasons must be provided to depart from precedent. Predictability, stability, and equal application of rules are critical to the Court's own legitimacy. In its most contemporary extended disquisition on stare decisis, in Planned Parenthood of Pennsylvania v. Casey, the Court explained: "[W]e recognize that no judicial system could do society's work if it eyed each issue afresh in every case that raised it. Indeed, the very concept of the rule of law underlying our own Constitution requires such continuity over time that a respect for precedent is, by definition, indispensable." ${ }^{61}$ In Casey, the Court outlined several bases for departing from precedent-unworkability, erosion, lack of reliance, and changed factual conditions-together which amount to articulating persuasive and substantial reasons for departing from the established legal rule while also upholding the rule of law. ${ }^{62}$ The usual practice of law and reasons for its efficacy include consistent and transparent reaffirmation of the rules (the precedents) through their repetition (restatement and application) by courts and lawyers.

Unlike judicial opinions, treatises do not have the force of law and they do not serve as precedential authority for courts. At best, they are persuasive authority. They are nonetheless indispensable to judicial decision-making and the rule of law because they provide information about consistent patterns and outliers in legal precedent on which courts often rely. The legal treatise has a centuries-long pedigree that grew out of "the abridgment tradition." 63 As A.W.B. Simpson explains:

The collapse in the seventeenth century of the collective exercises of learning in the Inns [of Court], the increase in the size of the legal profession, and the proliferation of nonauthoritative printed texts, could only lend support to the suggestion that the common law was no more than an ungodly jumble .... One reaction to all this had been practical. From the fifteenth century onwards lawyers had been attempting to reduce the unwieldy mass of legal materials, sometimes for their own personal use and sometimes cooperatively, by digesting it under titles arranged, for the want of any better system, alphabetically. This generated the abridgments and common-place books, which remained dominant forms of legal literature until the nineteenth century. The systematizing efforts of the compilers of abridgments could make possible the production of treatise literature based upon an analysis of the material abridged. ${ }^{64}$

The "great" treatises would not be written until the eighteenth and nineteenth centuries. These include William Blackstone's Commentaries in England ${ }^{65}$ and Joseph Story's series of nine treatises in the United States. ${ }^{66}$ The U.S. tradition culminated in the twentieth century with John Henry Wigmore's treatise on evidence,

61. 505 U.S. 833, 854 (1992) (citing BENJAMIN CARDOZO, THE NATURE OF THE JUdiCIAL PROCESS 149 (1921); Lewis F. Powell, Jr., Stare Decisis and Judicial Restraint, 1991 J. SuP. CT. HIST. 13, 16 (1991)). Note the reference in this description of stare decisis to Cardozo, who was instrumental in facilitating the founding of the ALI.

62. Id.

63. A.W.B. Simpson, The Rise and Fall of the Legal Treatise: Legal Principles and the Forms of Legal Literature, 48 U. CHI. L. REV. 632, 638 (1981).

64. Id. at 639 .

65. WiLliam BLACKStone, COMMENTARIES ON THE LAWS OF ENGLAND (1765-69).

66. Simpson, supra note 63 , at 670 (citing all nine). 
Samuel Williston's and Arthur Corbin's treatises on contracts, and Austin W. Scott's on trusts. ${ }^{67}$

As this brief history makes clear, treatises are generally authored by a single person (although, to be sure, authors usually have administrative and research help). This means treatises are liable to have character and take positions. ${ }^{68}$ But, as Simpson writes, "early American legal writers were anxious to demonstrate that the enterprise in which they were engaged, the exposition of the American common law, was a respectable one." ${ }^{\prime}$ At their best, treatises of this genre "unfold the rules, the principles, the reasons, which not only governed former decisions, but are to govern subsequent ones." ${ }^{\prime 70}$ They categorize and order their legal subject to help courts decide cases. This endeavor becomes especially helpful when no binding authority exists on the issue in the relevant jurisdiction but cases on point exist in other jurisdictions that may be unfamiliar or hard to find. ${ }^{71}$ Treatises also often summarize and highlight the patterns and themes in cases based on similar or contrasting statutory language and public policy, which may be relevant to the issues before a court. $^{72}$ And treatises provide historical perspectives of changes over time and trends in the case law that courts sitting in singular jurisdictions may seek to understand when deciding cutting-edge legal issues. ${ }^{73}$ The treatise's biggest limitation-its singular titular author-is addressed by two of its enduring features: the reputation of the author (many of whom have been esteemed lawyers or law professors) and its erudition. ${ }^{74}$ As Joseph Story explained in his preface to the Commentaries on Equity Jurisprudence, demonstrating deep and thorough knowledge of the field: "In many cases I have endeavoured to show the reasons, upon which these doctrines are founded, and to illustrate them by principles drawn from foreign jurisprudence, as well as from the Roman Civil Law." 75

According to treatise historians, the Restatement and uniform legislation projects are "the most recent expressions of this natural evolution" of a retelling or

67. Id. at 674 (citing these treatises). Wigmore and Corbin were also leaders in ALI Restatement projects.

68. For critiques on these grounds of the leading copyright treatises and an argument that a Restatement of Copyright Law is a superior legal resource, see Ann Bartow, A Restatement of Copyright Law as More Independent and Stable Treatise, 79 BROOK. L. REV. 457 (2014); Ann Bartow, The Hegemony of the Copyright Treatise, 73 U. CIN. L. REV. 581 (2004).

69. Simpson, supra note 63, at 671.

70. Id. at 674 (quoting Joel PRENTICE Bishop, The First BoOK OF THE LAW (1868)).

71. Richard Danner, Oh, the Treatise!, 111 Mich. L. REV. 821, 829 (2013) (“[T] he precedentbased, multijurisdictional U.S. system "was inherently costly to work with. It required time-taking search for authorities." (quoting JAMES WILlARD HuRST, THE GROWTH OF AMERICAN LAW: THE LAW MAKERS 308 (1950)); see also id. at 833 (describing how treatises "helped harried lawyers make sense of the raw materials ... [and] provided context and structure to the flood of published cases").

72. Id. at $824-25$.

73. Id. at $826-28$.

74. Most treatise authors have administrative and editorial help, as mentioned above, supra text accompanying note 68 , but this does not affect the evaluation of the treatise's authorship as emanating from a single source.

75. Simpson, supra note 63, at 673 (quoting JOSEPH StORY, COMMENTARIES ON EQUiTy JURISPRUDENCE, at iv (1836)). 
summarizing of the law. ${ }^{76}$ Restatements of law rely on stare decisis and share characteristics with legal treatises, including their purpose of summary, categorization, and bringing order to an unwieldy common law. Restatements do not, however, have the singular author limitation of treatises. And so, drafted by committee and subjected to multi-layers of approval processes, one might think a Restatement even more reliable than a legal treatise.

In the case of the Restatement of Copyright Law, questions have been raised about its legitimacy in light of its statutory context. ${ }^{77}$ But why should that be so? As the following Section explains in more detail, a statute is no less in need of interpretation than the common law. To be sure, the historical focus of most Restatement projects has been state law with the stated aim of coordinating legal practice in light of more than fifty distinct jurisdictions. ${ }^{78}$ This helped facilitate the interstate practice of law. By design, federal law does not present a coordination problem of the same magnitude. But that does not render a Restatement of Copyright Law illegitimate. Federal circuit courts generate circuit splits that are rarely clarified by the U.S. Supreme Court with its dwindling docket. ${ }^{79}$ Even in the absence of splits of authority, as Part III discusses, the current federal statutes have generated more than tens of thousands of federal court decisions that have left copyright law cluttered and in need of coordination. ${ }^{80}$ And, as the following Part also describes in more detail, the application of central copyright doctrines relies on state law. ${ }^{81}$ Restating those doctrines in light of the variation around the nation is useful to achieve the ALI's mission of promoting "the clarification and simplification of the law and its better adaptation to social needs ... [and] to secure the better administration of justice." 82

The 1976 Copyright Act's retelling in a Restatement as part of its interpretation and application for future uses is both inevitable and essential because of its statutory nature: the generality of the Act's language, ${ }^{83}$ the change in time and circumstances since its inception; ${ }^{84}$ and copious judicial copyright precedent, especially since the digital age, that has rendered copyright law more relevant than ever before. ${ }^{85}$ Each of these factors explains (and may justify) diverse statutory interpretations and

76. Id. at 675 .

77. See supra text accompanying notes 5-11.

78. See Past and Present ALI Projects, AM. L. INST. (Dec. 2020), https://perma.cc/S5C3-SV8N (listing all ALI projects past and present).

79. Ryan J. Owens \& David A. Simon, Explaining the Supreme Court's Shrinking Docket, 53 WM. \& MARY L. REV. 1219, 1242 (2012).

80. See infra Part III.

81. See infra Part III.

82. How the Institute Works, supra note 1.

83. As Part III discusses in more detail, phrases such as "works of authorship" and "transitory duration" are at the center of current copyright debates and subject to contested interpretations. As Part III explains, in some instances and as is common with statutory drafting, the 1976 Copyright Act intentionally includes ambiguous and broad language in order to be adaptable and flexible.

84. The 1976 Act is now forty-five years old and predates the age of the personal computer and the internet era. The substantiality of technological, social, and economic changes in copyright industries since 1976 cannot be overstated.

85. See Jessica Silbey, Against Progress: Interventions About Equality in Supreme Court Cases About Copyright Law, 19 CHI-Kent J. InTELl. PROP. 280, 280-81 (2020) (describing the rise of intellectual property cases and the field's increasing relevance to everyday life in the twenty-first century). 
applications, which collect over time into a mass of "copyright law" - a veritable common law of copyright, undoubtedly grounded in the 1976 Copyright Act - in need of "clarification and simplification." These inevitable features of legal evolution may produce doctrinal ambiguity and conflict, which the Restatement of Copyright Law can highlight as doctrinal strands on which legal arguments may be based. This does not amount to legislating copyright but instead is the kind of exposition and clarification that have been hallmarks of past ALI projects. ${ }^{86}$

\section{B. The ReSTATEMENT AS UNREMARKABLE LEGAL INTERPRETATION}

We concede that statutory law may be interpreted in a different manner than the common law within legitimate legal customs and practices. ${ }^{87}$ But to us, this means only that one must justify the method of exposition and interpretation, not the fact of it. This raises the concern already mentioned in Part I about institutional legitimacy and membership, an enduring tension across ALI projects and not specific to this one. Once we concede that statutes need retelling-perhaps especially the 1976 Copyright $\mathrm{Act}^{88}$ - under what circumstances is the retelling legitimate, and by whom? This raises age-old questions (in law, as well as in history, religion, and literature) about clarifying constraints on interpretation to render legitimate the "restatement" of the subject text by the restatement authors.

Interpretation does not render the text unstable. Decades of debates within literary criticism make that clear. When Stanley Fish asked in 1982, "Is there a text in this class?," he did not mean to render unstable all texts and illegitimate their interpretations (although some certainly accused him of that). ${ }^{89}$ His reader-response theory of literary interpretation was a culmination of decades of literary history and theory debating the proper disciplinary constraints for reading and retelling of literature. Could the meaning of a text be found in its words alone? How does the history of its words dictate their meaning? Will knowing the writer's biography facilitate interpretation of her words? How do the imagined or real readers of the words at the time of writing (or later upon reading) determine the text's meaning?

86. One might argue that the Restatement of Copyright Law should not address statutory ambiguities, as any gaps or lack of clarity can be fixed by Congress alone. For the reasons stated in Part II.B, such an argument mistakenly leaves to the legislative branch a significant job for most lawyers: interpreting and applying ambiguous statutory provisions in light of new circumstances. Furthermore, the legislative branch is typically slow to respond to statutory ambiguities and gaps and usually does so only after lawyers and courts have addressed the issues in practice over time. Waiting for Congress to address statutory ambiguities hurts litigants and the administration of justice and is contrary to the ALI's mission. It also bears emphasizing that a Restatement of Copyright Law is not the Copyright Act. If Congress wants to fill a gap or clarify a statutory ambiguity, Congress can do that. And if Congress wants to avoid legislating, it can do that too. But one institution's delay or avoidance should not be the reason for another's, especially when the ALI is not making law and is merely restating it to facilitate others' administration of it. Finally, the fact that Congress may amend the law (or not) does not make a Restatement futile. It merely emphasizes law's unfinished and essentially open character.

87. Lief CARTER \& ThOMAS BuRKe, REASON IN LAW 68-101 (7th ed. 2004) (describing and distinguishing statutory interpretation from common-law development).

88. See infra Part III.

89. Stanley Fish, Is There a Text In This Class?: The Authority of Interpretive COMMUNITIES 305 (1980). 
As Guyora Binder and Robert Weisberg explain, "Fish initially set out to establish reader-centered criticism as a more objective rival to the text-centered New Criticism. Thus, his initial response to the proliferation of conflicting "close readings' was not to celebrate the creativity of the interpreter, but to seek to better constrain the interpreter." 90 They further explain that Fish's "method of doing so was to ... focus[] on the role of the reader expectations in structuring the reading experience." 11 Fish demanded we investigate the "social practice of reading" in order to identify a shared "system of rules that each [reader] ... has somehow internalized" rendering "understanding [of the text] . . in some sense . . uniform." 92

This account of literary interpretation was radical if only because it extended and diversified the origin of authority for meaning beyond the author and the text. In this way, its result was more democratic if perhaps also more stochastic. And this generated understandable critiques that focused on whether Fish could deliver on his theory, whether he was making empirical claims about all readers or just some readers (or even just one reader), and whether uniformity plausibly exists even among so-called "interpretive communities" that shared reading experiences and contexts. ${ }^{93}$ These were trenchant critiques of Fish's theory of interpretation, which produced refinements and focus, as reasoned and open debate often does. ${ }^{94}$

A "new pragmatism" arose in literary theory that drew on, among other features, textual genre and genre's role in constraining the reader's interpretation (including by asking genre-specific questions, such as whether something is a poem or a recipe). ${ }^{95}$ This had the benefit of retaining the importance of the author's intent but also of incorporating the reaction of an expected audience, whose composition will change over time alongside the evolution of the genre's contours. Genre is a social and institutional category as much as a literary one, defining a relationship between text and audience based on expectations conventionally assigned to words and textual form in a specific situation. ${ }^{96}$

What does all this have to do with the Restatement of Copyright Law? A statute, like a recipe or a poem, is a genre of text. ${ }^{97}$ As such, it calls out to be read in a specific way, and lawyers and judges (the text's typical readers) understand it in this fashion. ${ }^{98}$ Lawyers and judges expect that in the statutory context legislatures are the "authors" and that it is the lawyers' and judges' task to give meaning to the legislature's policy choices as embodied in the statutory text and structure. ${ }^{99}$ But it is not that simple. This task definition begs the question of how to "give meaning"

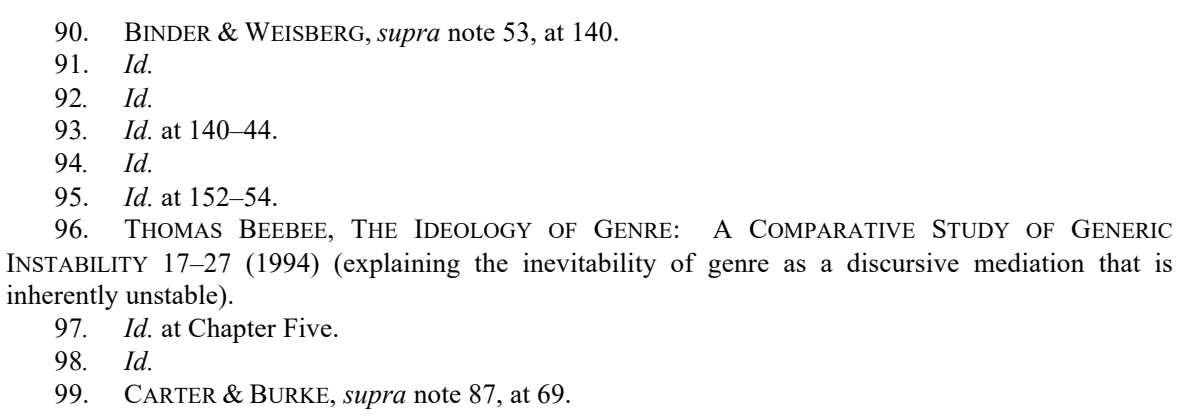


to the text as an expression of policy preferences. As Lief Carter and Thomas Burke write, "[j]udges who arm themselves with dictionaries and expect to find a single, unproblematic interpretation of a statute expect too much of language - and too little of themselves." 100 The 1976 Copyright Act is no exception. It contains some very specific provisions (such as the exemptions of certain performances and displays from copyright infringement in $\S 110^{101}$ ) and also uses broad, general language (such as the subject matter of copyright in $\S 102^{102}$ ). Communities of readers must interpret words in the statutory context and attend to evolving factual circumstances. Given a statute's complexity and variable relevance in diverse contexts, its interpretation is likely to generate diverse results.

Statutes are also more than words. They are complex, multi-layered texts produced over time in the context of committee reports, floor speeches, and testimony. The 1976 Copyright Act in particular was written over the course of more than a decade of stakeholder convenings and public hearings with explicit but broadly worded compromises baked into the statute. ${ }^{103}$ The industries on whose behalf those compromises were struck, such as the book publishing, music, and computer industries, have been so transformed in the digital age that a judge or lawyer would be forgiven for struggling to interpret and apply statutory provisions drafted for industries that would be unrecognizable today. ${ }^{104}$ And yet, they do apply the statute to new circumstances because that is their job. ${ }^{105}$ The "interpretive communities" of judges and lawyers are relatively coherent in terms of professional standards and norms, driven by consistency among legal institutions and education (especially as opposed to readers of novels or movie audiences whose diversity is by definition as varied as the consuming public). ${ }^{106}$ And yet, the 1976 Copyright Act (like all statutes) is addressed to readers of uncertain size and scope for a period of uncertain time. ${ }^{107}$ Indeed, the authors of the 1976 Copyright Act, writing a "statute

\footnotetext{
100. Id. at 107 .

101. 17 U.S.C. $\S 110$.

102. Id. $\S 102$.

103. Jessica Litman, Digital COPYRIGHT 35-76 (2001) (providing a history of copyright lawmaking in the twentieth century).

104. The music industry - with its transformed distribution and production mechanisms - is only one such example. The Music Modernization Act of 2019 was one attempt at updating the Copyright Act in light of these changes. Pub. L. No. 115-264, 132 Stat. 3676 (2018) (codified in scattered sections of 17 U.S.C.). The Copyright Office describes it as "the most significant piece of copyright legislation in decades and updates our current laws to reflect modern consumer preferences and technological developments in the music marketplace." The Music Modernization Act, U.S. COPYRIGHT OFF., https://perma.cc/3L9P-66M2 (last visited Jan. 14, 2021).

105. See Marbury v. Madison, 5 U.S. 137, 177 (1803) (describing the function of the judiciary in the process of applying a federal statute, the Judiciary Act of 1789, is to "say what the law is").

106. CARTER \& BURKE, supra note 87 , at 10-13.

107. See BINDER \& WEISBERG, supra note 53, at 149 ("The texts of greatest interest to hermeneutic theorists - literary, scriptural, and legal texts - are all addressed to groups of readers of uncertain scope. In discussing legal texts such as legislation, [literary theorist E.D.] Hirsch admits that their authors may intend to delegate discretion to unknown later interpreters to apply these texts in light of their own experience.").
} 
for the ages," undoubtedly intended to delegate discretion of its interpretation to unknown lawyers and judges later in time. ${ }^{108}$

What justifies this delegation of interpretation to future "restaters" of the law whose interpretations are expected to extend and amplify the statute's future authority? One answer is the rule of law, as stated above. ${ }^{109}$ Judges and lawyers are disciplined and incentivized to avoid and constrain individual moral feelings in their interpretation and application of law. ${ }^{110}$ Perhaps less like literary critics than Stanley Fish would like to admit, lawyers and judges participate in clearly delineated interpretive practices defined by constraining features of legal reasoning, such as text, precedent, historical record, federalism, and democratic theory. ${ }^{111}$ Their professional reputations are staked on adhering to standards of legal reasoning that promote trustworthiness: transparency, accountability, and evenhandedness. ${ }^{112}$ Although lawyers often have obligations to advocate zealously for their clients, lawyers and judges nonetheless must justify their interpretation of the law in a particular case with reasons resting on impartial grounds mutually agreed upon within their community of professional colleagues. ${ }^{113}$ These include stating facts accurately and comprehensively, correcting legal and factual errors when discovered and keeping them to a minimum, and justifying choices made among various possible legal solutions with established rules of the trade. ${ }^{114}$ If lawyers and judges are perceived to be manipulating or ignoring these rules to reach partisan, selfinterested ends, cohesion in the community and faith in its object of just dispute resolution will ebb. ${ }^{115}$ There is much to incentivize cooperation in upholding the rule of law among professionals whose primary task is to interpret or "retell" it. And so, when the legislature relies on future lawyers and judges to retell and apply the statute enacted decades prior, they are anticipating an interpretive community constrained by these professional standards and goals of maintaining the public good of democratic governance. Why would we expect anything less of the lawyers, judges, and scholars crafting the Restatement of Copyright Law today?

A critic may answer by claiming that this Restatement project has too many law professors, and the majority of law professors in the copyright field tend to be of a single mind when it comes to copyright reform. Whether true or not, the criticism that legal academia produces too much liberal-leaning scholarship is not a new concern. It was there at the beginning of the ALI, as explained in Part I, and it has

108. See infra Part III.

109. See supra Part II.A.

110. CARTER \& BURKE, supra note 87 , at 3 .

111. Philip Bobbitt, Constitutional Fate: Theory of THe Constitution 7 (1982) (describing the six modalities of interpretation as historical, textual, doctrinal, prudential, structural, and ethical arguments).

112. CARTER \& BURKE, supra note 87, at 136-37; id. at 140 (describing the need for "neutral, dispassionate ... dispute resol[ution] [as being] greatest when disputes are most intense and when the legal decision will have a major impact on the lives of many people").

113. Owen M. Fiss, Objectivity and Interpretation, 34 STAN. L. REV. 739, 744 (1982) (describing how judicial and other authoritative interpreters of law are constrained by the norms of their communities of interpretation); see also BINDER \& WEISBERG, supra note 53, at 160-61 (describing Fiss's work).

114. CARTER \& BURKE, supra note 87 , at $142-50$.

115. Id. 
not derailed past Restatement projects. And whether copyright law professors in particular are somehow more partisan than the other legal scholars (a claim we dispute but accept for the purpose of argument here), the Restatement community is much more than law professors. In addition to legal scholars from all over the nation, Advisors, Liaisons, and Members Consultative Group to the project include copyright-industry lawyers who work both in-house and at law firms, judges, and professional organization leaders. ${ }^{116}$ The prefatory pages to the Tentative Draft No. 1 list affiliations as diverse as the field. ${ }^{117}$ And even if the concern is of these Reporters specifically - and we do not know that it is - these Reporters, just like those from projects before, promise to avoid or disclose all conflicts of interest and adhere to professional legal norms of honesty and diligence. ${ }^{118}$ Legal academics, like other lawyers and judges, are committed to the rules of professional conduct that include cultivating knowledge of the law, employing that knowledge to reform the law and strengthening legal education, and advancing the public's understanding of and confidence in the rule of law and our justice system. ${ }^{119}$ The ABA Model Rules of Professional Conduct also describe lawyers being "guided by personal conscience and the approbation of professional peers." 120 We should expect only the "highest level of skill, to improve the law and the legal profession and to exemplify the legal profession's ideals of public service" in this Restatement project, as with others. ${ }^{121}$

If we were to criticize the Restatement project at all as lacking legitimacy of democratic engagement and inclusivity, it would be a criticism of the Restatement projects generally, not this one specifically. And this too has been an enduring tension in the ALI, as Part I explains. This speaks to the difference between Restatements and other legal authorities. A Restatement is not a judicial opinion or a legal brief; it is not a statute. If it lacks the breadth of participation we expect from the most authoritative of legal sources, that is because it is by its very nature an expert perspective constrained by the experts who participate and the process in which the opinions are rendered and accepted. Like legal treatises enthusiastically embraced

116. Participants, AM. L. INST., https://perma.cc/YSG2-G65K (last visited Jan. 11, 2021). To be sure, the Reporter is the lead on the project and, like most Reporters before him (including Wigmore, Scott, and Corbin), he is a law professor. Christopher Jon Sprigman, NYU LAW, https://perma.cc/8FJEKKER (last visited Dec. 14, 2020). The Reporter's job as a legal academic cannot reasonably be the basis to complain about the Restatement of Copyright Law because most past Reporters were academics and were so designated originally because they had more time to devote to the project compared to full-time practicing lawyers and judges. Elson, supra note 17, at 636 (explaining time constraints on practicing lawyers).

117. Restatement Tentative Draft No. 1 (2020), at vii-ix.

118. Like all ALI members, Reporters must provide "thoughtful, disinterested" analysis and "leave their clients at the door," meaning both actual clients and personal self-interest; the ALI's own rules require as much. AM LAW INST., COUNCIL R. 4.03 ("To maintain the Institute's reputation for thoughtful, disinterested analysis of legal issues, members are expected to leave client interests at the door.... Members should speak, write, and vote on the basis of their personal and professional convictions and experience without regard to client interests or self-interest."); Policy Statement and Procedures on Conflicts of Interest with Respect to Institute Projects, AM. LAW InST. (May 17, 2010) https://perma.cc/QM6T-NGEC (citing ABA Model Rules of Professional Conduct, Preamble $\uparrow \uparrow$ 2, 4).

119. ABA Model Rules of Professional Conduct, Preamble $₫ 6$.

120. Id. ๆ 7.

121. Id. 
by lawyers and judges and cited with frequency, ${ }^{122}$ the Restatement is one view on the state of the law. It is a collective view-not a singular one - and for that reason, maybe it is an improvement on solo-authored treatises. ${ }^{123}$ But the Restatement remains persuasive authority, at best, whose authority is grounded in respect for the ALI. The ALI Restatements are perhaps more persuasive than amicus briefs and experts at trial, which are nevertheless encouraged and considered seriously by courts. Restatements are likely to remain welcome and relied upon as long as clarification of the law remains necessary and the ALI remains a reputable professional organization dedicated to the rule of law.

Movements in literary theory over the twentieth century have focused on the same kind of struggle we see over the meaning of the 1976 Copyright Act in light of institutional legitimacy. Literary theories of textual interpretation disputed whether literary interpretation was more like an objective science or a subjective self-centered performance by the critic. ${ }^{124}$ But to focus on the literary in law is to miss the similar and coincident epistemological inquiries among historians, religion scholars, and legal professionals. ${ }^{125}$ These disciplines aim to discern through debate the meaning of authoritative texts and have done so for centuries. Each embraces the process of retelling as a feature of disciplinary practice, of knowing history, of understanding religion, and of practicing law. The point is not to avoid retelling, but to explain the contingencies of that retelling as a matter of disciplinary consensus that justifies the production of knowledge within each specialty. ${ }^{126}$

And so we return to the question: What explains the anxiety about retelling this statute? What prevents a professional consensus from arising regarding the contingencies of legal interpretation in the case of the 1976 Copyright Act? The anxiety that a Restatement of Copyright Law will lead to uncertainty, relativism, or even political polarization is a comment about the specific nature of this text, the state of the copyright industries today, and the community of interpreters. But these are old concerns that arose in earlier ALI endeavors and none justifiably undermines this Restatement project.

As stated above, the statutory genre does not thwart its need for interpretation because all statutes require interpretation to be effective. And as Part III describes, this particular statute has certain features making its retelling more necessary, if also more challenging. The distance from the textual writing and its current application

122. In the copyright field, those treatises include PAUL GOLDSTEIN, GOLDSTEIN ON COPYRIGHT (3d ed. 2020); MElville B. Nimmer \& DAVid NimMER, NimMER ON COPYRight (2020); and William F. PATRY, PATRY ON COPYRIGHT (2020).

123. See supra Part II.A.

124. BINDER \& WEISBERG, supra note 53, at 147.

125. See, e.g., James L. Kugel, How To Read the Bible: A Guide To Scripture, Then And Now (2012) (discussing and applying ancient and modern biblical interpretive methods); William W. Fisher III, Texts and Contexts: The Application To American Legal History of the Methodologies of Intellectual History, 49 STAN. L. REV. 1065 (1997) (describing methodological debates of interpretation in history). With regard to constitutional law, see WHITTINGTON, supra note 52.

126. For a notable exploration of this issue in the context of religion, see generally JAMES L. KUGEL, THE BIBLE AS IT WAS (1997) (explicating how the Bible itself is a retelling of many preexisting religious and cultural works). 
is substantial in the legal context. ${ }^{127}$ Although lawyers regularly interpret and apply constitutions and other laws that are centuries old, the older the texts are, the harder and more contestable their interpretations may become. ${ }^{128}$ The technological, economic, and social changes over the half-century since the 1976 Copyright Act was passed have made the statute's contours more relevant and more outdated. ${ }^{129}$ Courts all over the country are faced with copyright issues on an increasingly frequent basis in light of the internet era and are asked to interpret statutory language that speaks of "publication," "authorship," and "fixation in a tangible medium" as they were put into the statute before the internet. ${ }^{130}$ Lawyers and judges are doing an admirable job wrestling with the 1976 Copyright Act in a twenty-first century technological ecosystem, but they are doing it piecemeal, understaffed, and in light of a growing diversity of clients. What we have, then, is a veritable common law of copyright since the passage of 1976 Act (and in many cases from before), with proliferating decisions at rapid rates. ${ }^{131}$ And in the absence of a new statute, a Restatement can bring order to this body of law, which is exactly the ALI's mission. ${ }^{132}$ These factors render the stakes of retelling high and the possible variations in the retelling large. But these factors cry out for the need of a Restatement, not the avoidance of one.

And so, we are left with the possibility that the "interpretive community" charged with the Restatement of Copyright Law lacks the legitimacy required to render an authoritative retelling of the state of copyright law. And this returns us to "new pragmatism" in literary theory, which wrestled with much the same question thirty years ago when faced with the unraveling of the field as a university discipline. Interpretation is a convention-bound activity in which "interpreters are disciplined by community norms ... to be found in descriptive or prescriptive accounts of the institutions within which they read." 133 The source of the illegitimacy is not the fact of the retelling but the political context in which the telling is rendered. ${ }^{134}$ The current political context is unfortunately an increasingly ideologically polarized nation, dramatic and destabilizing wealth inequality, and enormous threats to the rule

127. See infra Part III.A.

128. WhitTINGTON, supra note 52, at 161 (discussing "intentional fallacy"); id. at 174 (discussing originalism as "the end of history").

129. See infra Part III.A.

130. See infra Part III.

131. See Scott D. Hampton \& Ashley J. Bailey, Intellectual Property Case Filing Trends Over the Last Decade, HAMPTON IP \& ECON. CONSUlTING (Feb. 11, 2020), https://perma.cc/YQM5-PGN7 (showing increase by $128 \%$ of copyright cases between 2010-2019).

132. This does not concede that a Restatement in the statutory context is any less legitimate than in the common law context. But a Restatement here brings order and organization to the cases in the absence of another kind of ordering.

133. BINDER \& WEISBERG, supra note 53, at 153.

134. Id. at 114. Binder and Weisberg root the crisis of judicial legitimacy to which legal hermeneutics responds in the resistance to the interpretation of the Civil War Amendments: "The legitimacy crisis in which American legal scholarship has struggled for the better part of a century [regarding constitutional interpretation] ... [have] roots ... in enduring cleavages in American society and politics, and its challenges are political rather than technical. If literary theory is to help us meet these challenges, it must do so in, and not in place of, politics." Id. 
of law that rival in intensity the decades just after World War I in the United States, when the ALI got off the ground. ${ }^{135}$ Do controversies related to copyright law reflect this unsettling political context? Maybe. ${ }^{136}$ We can never really separate ourselves from the particular time and place in which we are situated. Law is, after all "a practice that constantly appropriates, reproduces, and reshapes a culture."137 Doing law always incorporates materials from the present, precarious moment. But that does not make the practice of law-its interpretation and application-illegitimate. As lawyers, we have the capacity to shape and revitalize the very foundations we worry are being weakened, the professional standards and norms of legal reasoning, factual determinations, and evenhandedness that are the hallmarks of our "interpretive community" of lawyers and judges. The Restatement project has the chance to amplify these essential features of the legal profession and speak to the central questions of law's public meaning and value. And we have every reason to believe the Restatement of Copyright Law will do just that.

In restating the law of copyright for lawyers and judges who seek help organizing the complex field, the Restatement project is not wresting power from the 94th Congress which passed the 1976 Copyright Act. The Restatement participants are engaging in a broader, civic-minded project that all lawyers and judges engage in by asking how to understand this law (the statute) in light of all the other decisions, related laws, and constitutions. As James Boyd White has observed, "[i]n both the identification of texts and their construction, then, the lawyer is engaged in the special kind of lawmaking that respects certain judgments made by others," further stating that "[o]ne could hardly imagine a ... [task] more naturally public and civic in its nature, than that ... in which one constantly gives meaning not only to the immediate experience of others but to our shared past and present." ${ }^{138}$ Restatement participants are trained in the law, committed to the rule of law, and are participating in an integrated and democratic process of open debate with people of diverse perspectives who are experts in the field. As such, there is every reason to think a Restatement of Copyright Law will be as successful an ALI project as those that came before.

\section{COPYRIGHT'S RETELLING}

Retelling copyright law in a Restatement is as natural and useful of an endeavor as a Restatement of Contracts or Torts, even if copyright law is grounded in a federal statute. The 1976 Copyright Act, the principal federal statute governing copyright law, both draws on longstanding common law elucidated by the courts and signals courts to continue expounding the common law in essential ways. Moreover, as

135. See supra Part I.

136. Silbey, supra note 85 (describing trends in intellectual property cases over the past twenty years as being increasingly about deeply rooted but contested values, such as equality, rather than about market competition, which is typically the focus of intellectual property).

137. BINDER AND WEISBERG, supra note 53, at 27.

138. James Boyd White, From EXPeCtation to EXPERIENCE: EsSAys ON LAW AND Legal EDUCATION 176 (2000). 
Congress intimated when it enacted the 1976 Act, it was enacting a copyright statute for the ages. That Congress has not returned to revise the central aspects of the law in the past four decades strongly suggests that it was intended for long-term judicial interpretation. For these reasons, we should welcome a carefully crafted Restatement of Copyright Law to help courts and lawyers ascertain the central rules of copyright law. The provisions at issue in the Restatement of Copyright Law draft on which ALI membership will vote at ALI's upcoming annual meeting —originality, fixation, categories of copyrightable subject matter, the idea-expression distinction, and authorship and ownership - exemplify how valuable this project retelling copyright is. ${ }^{139}$ As set out in subsequent sections, these provisions demonstrate the benefits of a well-constructed Restatement of Copyright Law.

\section{A. A Statute for the Ages}

As discussed above, some have expressed discomfort with a Restatement of Copyright Law, even as they are at ease with Restatements of Contracts and Torts, because of the single federal statute at the base of U.S. copyright law. ${ }^{140}$ For example, some members of Congress recently urged that "laws created through federal statute, including federal copyright law, are ill-suited for treatment in a Restatement because the law is clearly articulated by Congress in both the statute and the legislative history." 141 They elaborated that "any Restatement or other treatise relied on by courts that attempts to diminish the importance of the statutory text or legislative history relating to that text would warrant concern."142 Furthermore, they suggested that "[c]ourts should rely on that statutory text and legislative history, not Restatements that attempt to replace the statutory language and legislative history established by Congress with novel interpretations." 143

But the Congress that enacted the 1976 Copyright Act intended and expected courts to use common-law decision-making tools to interpret the core of the Act. The fact that copyright law originates from a federal statute does not obviate the need for its interpretation, and thus produces proliferating interpretations for reasons already discussed above in Part II. In particular, the 1976 Copyright Act contains particular sections, as explored below, that call out explicitly for common-law decision-making and have evolved in their application over time. These sections are concepts central to copyright law itself, including originality, fixation, copyrightable subject matter, the idea-expression distinction, and authorship. ${ }^{144}$ Specifically, the enacting Congress drew in large part on courts' common-law understandings of copyright law

139. We address only those provisions in the tentative draft to be voted on by ALI members at the upcoming ALI meeting this year. We do not understand other provisions, such as copyright law's distribution right as discussed in Shyamkrishna Balganesh \& Peter S. Menell, Restatements of Statutory Law: The Curious Case of the Restatement of Copyright, 44 CoLUM. J.L. \& ARTS 285, 324-37 (2021), to be finalized or up for a membership vote at this time.

140. See supra text accompanying notes 5-11.

141. Letter from Sen. Tillis et al., supra note 9.

142. Id.

143. Id.

144. See infra Part III.B-F. 
to shape the Act and signaled that courts should continue using its common-law approach to interpret the Act. ${ }^{145}$ As such, a retelling of these statutory provisions and how courts have interpreted them is not only helpful to lawyers and courts in understanding copyright law, but also accords with the enacting Congress's statutory framework. Of course, even with the common-law-making approach that is so fundamental to much of the copyright statute, the formulators of the Restatement must take extraordinary care not to deviate from the statute and the courts' interpretations of that statute, as we discuss in the subsequent sections.

To be sure, there are less central parts of the 1976 Copyright Act - such as the eleven subsections of 17 U.S.C. $\$ 110$ exempting from infringement certain performances and displays, particularly some nonprofit and educational ones, and detailed rules in 17 U.S.C. $\S 111$ governing secondary transmissions of broadcast programming by cable systems - that are less amenable to exposition and retelling. Because these statutory sections are byzantine in their details, less clarity can be gained and more accuracy can be lost by retelling them rather than referencing them.

Although Congress has made some amendments to the 1976 Copyright Act, including the Copyright Term Extension Act, ${ }^{146}$ the Architectural Works Copyright Protection Act, ${ }^{147}$ and the Digital Millennium Copyright Act, ${ }^{148}$ it has left the core of the Act - with its rules of copyrightability, exclusive rights, infringement, and exclusions from infringement-virtually intact for the past four decades. When Congress enacted the 1976 Copyright Act, the most recent major revision of the federal copyright laws since 1909, it did so in large part because so many technologies - including motion pictures, sound recordings, radio, television, and communications satellites - had since become more commonplace and had affected the creation, copying, and distribution of copyrighted works in ways not anticipated by and not accommodated in the 1909 Act. ${ }^{149}$ As discussed in the following sections, with the 1976 Act, Congress chose to create a copyright statute for the ages by enacting generally applicable rules that courts could interpret and apply even with regard to technologies unforeseen at the time. ${ }^{150}$ Indeed, even though many more technologies have been created or become popular since-from the VCR and DVR to the internet to search engines and social media - Congress has not undertaken a major revision to the 1976 Act, and courts have addressed the implications for copyright law of such later-developed technologies by applying the 1976 statutory framework. ${ }^{151}$

145. See infra Part III.B-F.

146. Sonny Bono Copyright Term Extension Act, Pub. L. No. 105-298, §§ 101-106, 112 Stat. 2827, 2827-29 (1998) (codified as amended at 17 U.S.C. $\S \S 301-304$ ).

147. Pub. L. No. 101-650, $\S$ 701-706, 104 Stat. 5133, 5133-34 (1990) (codified as amended at 17 U.S.C. $\S \S 101-102,120,301)$.

148. Pub. L. No. 105-304, 112 Stat. 2860 (1998) (codified as amended throughout 17 U.S.C.)

149. H.R. REP. No. 94-1476, at 47-50 (1976); S. REP. No. 94-473, at 47 (1975).

150. See infra Part III.B-F.

151. Sony Corp. of Am. v. Univ. City Studios, Inc., 464 U.S. 417 (1984) (VCR); Cartoon Network LP v. CSC Holdings, Inc., 536 F.3d 121 (2d Cir. 2008) (DVR); Perfect 10, Inc. v. Amazon.com, Inc., 508 F.3d 1146 (9th Cir. 2007) (search engine); Goldman v. Breitbart News Network, LLC, 302 F. Supp. 3d 
In light of both the common law-esque statutory framework that Congress enacted in the 1976 Act and congressional desire to create a statute for the ages, a Restatement of Copyright Law, done thoughtfully and well, can help guide courts, lawyers, and law students, just as a Restatement of Contracts or Torts can. If the distance between the 1909 and 1976 Acts is any indication, Congress will not be overhauling the copyright laws until approximately 2043. Because of a shift in the political economy of copyright in recent decades, it might be even less likely that there is a major overhaul of central aspects of the copyright statute in the near or even distant future. The 1976 Act itself was the result of decades of negotiation and compromise among content creators and distributors in various industries. ${ }^{152}$ Since then, with the rise of powerful online content intermediaries such as Google, the landscape has become further divided between those that favor stronger copyright protection and those that oppose it. ${ }^{153}$ The shift in political economy provides further reason to suspect that major legislative changes to the core of the copyright statute are unlikely, at least in the short term, giving a well-done Restatement of Copyright Law decades or more to be useful.

We now turn to specific core provisions of the Copyright Act - those governing originality, fixation, copyrightable subject matter, the idea-expression distinction, and authorship and ownership - to illustrate how the Restatement of Copyright Law is an appropriate and welcome retelling of copyright law.

\section{B. Originality}

The Restatement's provisions on copyright law's originality requirement usefully retell the requirement by synthesizing the courts' longtime common-law development of originality. This was Congress's intent when it invoked and inserted the courts' understanding of the requirement into the 1976 Act without defining it.

The 1976 Act provides copyright protection to "original works of authorship."154 In explaining this choice of phrasing, congressional legislative history emphasized that " $[\mathrm{t}]$ he phrase 'original works of authorship,' which is purposely left undefined, is intended to incorporate without change the standard of originality established by the courts under the present [1909] copyright statute."155 As the Supreme Court has made clear in a copyright case (and many other contexts too), "[i]t is ... well

585 (S.D.N.Y. 2018) (social media); Religious Tech. Ctr. v. Netcom On-Line Comm. Servs., Inc., 907 F. Supp. 1361 (N.D. Cal. 1995) (internet).

152. Jessica D. Litman, Copyright, Compromise, and Legislative History, 72 CORNELL L. REv. 857, 859 (1987).

153. Guy Pessach, Deconstructing Disintermediation: A Skeptical Copyright Perspective, 31 CARDOZO ARTS \& ENT. L.J. 833, 838-39 (2013); Joel Reidenberg, The Rule of Intellectual Property Law in the Internet Economy, 44 Hous. L. REV. 1073, 1073-76 (2007).

154. 17 U.S.C. § 102(a).

155. H.R. REP. NO. 94-1476, at 51 (1976); S. REP. NO. 94-473, at 50 (1975); $c f$. SUPPLEMENTARY ReP. OF THE REg. OF COPYRIGHTS ON THE GEN. REVISION OF U.S. COPYRIGHT LAW, 89TH CONG., 1ST SESS., pt. 6, p. 3 (H. Judiciary Comm. Print 1965) ("Our intention here is to maintain the established standards of originality ..."). Both congressional reports elaborated that "[t]his standard does not include requirements of novelty, ingenuity, or esthetic merit, and there is no intention to enlarge the standard of copyright protection to require them." H.R. REP. NO. 94-1476, at 51; S. REP. NO. 94-473, at 50. 
established that where Congress uses terms that have accumulated settled meaning under the common law, a court must infer, unless the statute otherwise dictates, that Congress means to incorporate the established meaning of these terms." 156 By explaining that it was "purposely le[aving] undefined" the term "original," Congress in the 1976 Act was statutorily asking courts to interpret the term in light of the common-law meaning that the courts had already been attributing to "original."157 Congress was calling upon courts to continue common lawmaking along the same general path as they had previously been doing.

In its first major interpretation of the originality requirement under the 1976 Act, the Supreme Court in Feist Publications, Inc. v. Rural Telephone Service Co. ruled that "[o]riginal, as the term is used in copyright, means only that the work was independently created by the author (as opposed to copied from other works), and that it possesses at least some minimal degree of creativity."158 The Feist Court derived this interpretation from a long line of cases that understood originality to be constitutionally required based on congressional authorization to pass copyright laws protecting the "Writings" of "Authors."159 Feist distilled its understanding of originality in part from two nineteenth-century Supreme Court decisions. ${ }^{160}$ One construed "Writings" to be only those that "are original, and are founded in the creative powers of the mind. The writings which are to be protected are the fruits of intellectual labor, embodied in the form of books, prints, engravings, and the like." 161 The other construed "Authors" to be "he to whom anything owes its origin; originator; maker," and limited copyright to "original intellectual conceptions of the author." 162 Feist proceeded to elaborate why these analyses mean facts are never original but compilations of fact might sometimes nonetheless be original. ${ }^{163}$

In subsequent decisions building on Feist and its predecessors, courts continued to refine the legal understanding of originality. For example, the Tenth Circuit held that digital wire-frame models of cars are not original because they "are not so much independent creations as (very good) copies of [the underlying] vehicles." 164 The Eleventh Circuit ruled that blank forms for emergency room doctors to record encounters with patients are not original because they lack creativity for not conveying information. ${ }^{165}$ And the Northern District of California held that there can be sufficient creativity in HTML code to be original. ${ }^{166}$ As these examples

156. Cmty. for Creative Non-Violence v. Reid, 490 U.S. 730, 739 (1989) (internal marks omitted).

157. H.R. REP. No. 94-1476, at 51 (1976); S. REP. No. 94-473, at 50 (1975).

158. 499 U.S. 340, 345 (1990)

159. Id. at 346 (quoting U.S. CONST. art. I, § 8, cl. 8)

160. Id. at 346-47.

161. In re Trade-Mark Cases, 100 U.S. 82, 94 (1879).

162. Burrow-Giles Lithographic Co. v. Sarony, 111 U.S. 53, 58 (1884).

163. Feist, 499 U.S. at 347-51. For an exploration of the Supreme Court's originality decisions and the Restatement's attempt to "stick to a centrist, sometimes minimalist, narrative of Feist's two-step framework" in view of case law concerning copyright in compilations and other works, see Justin Hughes, Restating Copyright Law's Originality Requirement, 44 COLUM. J.L. \& ARTS 383, 409 (2021).

164. Meshwerks, Inc. v. Toyota Motor Sales U.S.A., Inc., 528 F.3d 1258, 1264 (10th Cir. 2008).

165. Utopia Provider Sys., Inc. v. Pro-Med Clinical Sys., LLC, 596 F.3d 1313, 1319-24 (11th Cir. 2010).

166. Media.net Advert. FZ-LLC v. NetSeer, Inc., 156 F. Supp. 3d 1052, 1065-67 (N.D. Cal. 2016). 
illustrate, courts have continued to apply the common-law framework of originality clarified in Feist to new situations, new industries, and new forms of expression.

The Restatement of Copyright Law's treatment of the originality requirement synthesizes the courts' common-law approach that Congress anticipated and specified. Section 5 restates the statutory language - that "[ $t$ ]he Copyright Act grants protection to "original works of authorship" - and then Feist's interpretation of that language in light of over a century of common lawmaking on originality. ${ }^{167}$ It says that "[f]or a work to be original, the work must be independently created by its author, as discussed in $\S 6$, and must embody expression that is at least minimally creative, as discussed in $\S 7 . " 168$

Section 6 explains further that a work is independently created "if the author has contributed some expression to the work without copying that expression from any preexisting work." 169 As courts have frequently emphasized, ${ }^{170}$ the Section's Comments elaborate that independent creation does not presuppose novelty, a much harder requirement to meet: "In order to be independently created, expression must not be copied in its entirety from any preexisting work; the expression need not be novel or unique." " Furthermore, Comment $b$ to $\S 6$ explains that "[t]he fact that an author's expression resembles a preexisting work does not mean that the author's expression was not independently created, so long as the author did not, in fact, copy that preexisting work." 172

Section 7 draws directly on Feist in elaborating the requirement that a work be minimally creative to be original: "The requirement that a work embody expression that is at least minimally creative can be satisfied by an author's creative choices." 173 It continues to explain that "[i]n the case of a compilation, choices regarding the selection, coordination, or arrangement of elements can satisfy the minimalcreativity requirement even if those elements are not themselves original." $" 174$

Further drawing on Feist and other case law, the Restatement specifies what does not constitute the requisite minimal creativity: routine choices, ${ }^{175}$ externally

167. Restatement Tentative Draft No. 1 (2020) $\S 5$, at 55.

168. Id. Section 5's Comments elaborate on the constitutional origins of the originality requirement. Id. $\S 5 \mathrm{cmt}$. a, at 55 .

169. Id. §6 at 58

170. E.g., Feist Publ'ns, Inc. v. Rural Tel. Serv. Co., 499 U.S. 340, 345-46 (1991) (“Originality does not signify novelty; a work may be original even though it closely resembles other works so long as the similarity is fortuitous, not the result of copying. To illustrate, assume that two poets, each ignorant of the other, compose identical poems. Neither work is novel, yet both are original and, hence, copyrightable." (citing Sheldon v. Metro-Goldwyn Pics. Corp., 81 F.2d 49, 54 (2d Cir. 1936)); Situation Mgmt. Sys., Inc. v. Asp. Consulting LLC, 560 F.3d 53, 60 (1st Cir. 2009); Wihtol v. Wells, 231 F.2d 550, 553 (7th Cir. 1956); Alfred Bell \& Co. v. Catalda Fine Arts, Inc., 191 F.2d 99, 102 (2d Cir. 1951).

171. Restatement Tentative Draft No. $1(2020) \S 6 \mathrm{cmt}$. b, at 58 .

172. Id.

173. Restatement Tentative Draft No. 1 (2020) § 7, at 63 (summarizing Feist, 499 U.S. at 345-61).

174. Id.

175. Id. § 7(c), at 63; see also Matthew Bender \& Co. v. West Publ'g Co., 158 F.3d 674, 682 (2d Cir. 1998) (summing up this rule before applying it to the creativity of West's arrangement of cases) (citing Feist, 499 U.S. at 362 (alphabetic white pages telephone directory); BellSouth Adver. \& Publ'g Corp. v. Donnelley Info. Publ'g, Inc., 999 F.2d 1436, 1444 (11th Cir. 1993) (en banc) (organization of yellow pages telephone directory)). 
constrained choices, ${ }^{176}$ and significant investments of labor, time, or skill, without more. ${ }^{177}$

The Restatement's provisions on originality usefully restate copyright law by synthesizing the courts' longstanding development of case law on this requirement in light of new situations and industries. By not defining "original works of authorship" in the 1976 Act, Congress intentionally adopted the courts' common-law understanding of the originality requirement and expected the courts to continue developing it in future cases. By synthesizing this case law and summarizing it appropriately in $\S \S 5-7$, the Restatement guides courts, lawyers, and others looking for an elaboration of the originality requirement that is nowhere provided in the statute itself.

\section{Fixation}

Copyright law's fixation requirement illustrates a different way in which the Restatement usefully retells copyright law. With originality, Congress relied on existing and future common-law development to define the term. With fixation, Congress expressly directed lawyers and judges to adapt this requirement for future technologies, leaving the requirement explicitly adaptable to future technologies without the need for congressional revision. The Restatement collates the various ways courts have interpreted and applied this forward-looking statutory standard as technological circumstances have changed.

The 1976 Act provides that to be copyrightable, works must be "fixed in any tangible medium of expression, now known or later developed, from which they can be perceived, reproduced, or otherwise communicated, either directly or with the aid of a machine or device." ${ }^{\text {"78 }}$ The Act elaborates that a work is " "fixed' in a tangible medium of expression when its embodiment in a copy or phonorecord, by or under the authority of the author, is sufficiently permanent or stable to permit it to be perceived, reproduced, or otherwise communicated for a period of more than transitory duration." 179 The legislative history on this provision states that "the

176. Restatement Tentative Draft No. 1 (2020) § 7(c), at 63; see also Matthew Bender, 158 F.3d at 682 (summing up this rule before applying it to the creativity of West's arrangement of cases) (citing Mid Am. Title Co. v. Kirk, 59 F.3d 719, 722 (7th Cir. 1995) (title examiner reports); Victor Lalli Enters., Inc. v. Big Red Apple, Inc., 936 F.2d 671, 672 (2d Cir. 1991) (charts of statistics on horse races)); Comput. Assocs. Int'l, Inc. v. Altai, Inc., 982 F.2d 693, 709-10 (2d Cir. 1992) (applying this principle to computer programs, and reasoning that "a programmer's freedom of design choice is often circumscribed by extrinsic considerations such as (1) the mechanical specifications of the computer on which a particular program is intended to run; (2) compatibility requirements of other programs with which a program is designed to operate in conjunction; (3) computer manufacturers' design standards; (4) demands of the industry being serviced; and (5) widely accepted programming practices within the computer industry").

177. Restatement Tentative Draft No. 1 (2020) §7(d), at 63; see also Feist, 499 U.S. at 354 ("Without a doubt, the 'sweat of the brow' doctrine flout[s] basic copyright principles."). On externally constrained choices, the Restatement notes that they include "the function the work is intended to serve, the tools used to produce the work, or practices or conventions standard to a particular type of work." Restatement Tentative Draft No. 1 (2020) § 7(c), at 63.

178. 17 U.S.C. § 102(a).

179. Id. $\S 101$. 
definition of 'fixation' would exclude from the concept purely evanescent or transient reproductions such as those projected briefly on a screen, shown electronically on a television or other cathode-ray tube, or captured momentarily in the 'memory' of a computer."'180

Congress sought to achieve multiple goals with the fixation requirement in the 1976 Act. First, it inaugurated federal copyrightability at the point of fixation, a time earlier than under the 1909 Act, which required that a work be published (or registered) for copyright protection. ${ }^{181}$ Second, the 1976 Act detailed numerous criteria required for fixation, including "sufficient[] permanen[ce] or stab[ility]" and "a period of more than transitory duration."182 Third, Congress allowed the fixation requirement to be satisfied when a work could be communicated "either directly or with the aid of a machine or device," which overturned a line of judicial rulings that, to Congress, perpetuated "the artificial and largely unjustifiable distinctions ... under which statutory copyrightability in certain cases has been made to depend upon the form or medium in which the work is fixed." 183

Perhaps most importantly for present purposes, Congress made clear in its statutory wording that it wanted to avoid being compelled to revise this fixation requirement as technologies evolved. Congress specified that the rule would require fixation "in any tangible medium of expression, now known or later developed." 184 By adding these last five words, which might otherwise seem unnecessary, Congress signaled that courts should interpret and apply the fixation standard as they do to conventional books, films, and other already-existing media also to after-developed technologies not yet conceived. ${ }^{185}$

Indeed, as new technologies developed, courts applied and clarified the statutory standard for new media and contexts. ${ }^{186}$ Consider videogames. In 1982, the Third Circuit reasoned that an arcade video game satisfied the fixation requirement even though "the video game generates or creates 'new' images each time [it is played], notwithstanding the fact that the new images are identical or substantially identical

\footnotetext{
180. H.R. REP. NO. 94-1476, at 53 (1976).

181. Act of Mar. 4, 1909, ch. 320, §§ 9-22.

182. 17 U.S.C. $\$ 101$.

183. H.R. REP. No. 94-1476, at 52; S. REP. No. 94-473, at 51 (1975). Congress was thereby overturning a rule that had principally been established by White-Smith Music Publ'n Co. v. Apollo Co., 209 U.S. 1 (1908), with regard to player piano rolls.

184. 17 U.S.C. § 102(a) (emphasis added).

185. Congress did specifically address one important technology: live broadcasts. According to the House Report, "the definition of 'fixation' would exclude from the concept purely evanescent or transient reproductions such as those projected briefly on a screen, shown electronically on a television or other cathode ray tube." H.R. REP. NO. 94-1476, at 53. Congress made the choice to protect "live broadcastssports, news coverage, live performances of music, etc.- - that are reaching the public in unfixed form but that are simultaneously being recorded." Id. at 52 . It did so by adding the following sentence to the statute: "A work consisting of sounds, images, or both, that are being transmitted, is 'fixed' for purposes of this title if a fixation of the work is being made simultaneously with its transmission." 17 U.S.C. $§ 101$.

186. Moreover, courts interpreted the fixation requirement as to already-existing media. For example, a district court held that a bowl of perishable Vietnamese food is not fixed, reasoning that "a bowl of perishable food will, by its terms, ultimately perish," and "a bowl of food which, once it spoils is gone forever, cannot be considered 'fixed." Kim Seng Co. v. J \& A Importers, Inc., 810 F. Supp. 2d 1046, 1054 (C.D. Cal. 2011).
} 
to the earlier ones." 187 The court reasoned that "[t]he audiovisual work is permanently embodied in a material object, the memory devices, from which it can be perceived with the aid of the other components of the game."188 The court also rejected an argument that the player's participation in the videogame, which affected the audiovisual display shown, meant that the game was not fixed, reasoning that "there is always a repetitive sequence of a substantial portion of the sights and sounds of the game, and many aspects of the display remain constant from game to game regardless of how the player operates the controls." 189

The Ninth Circuit also found computer software loaded into a computer's random access memory (RAM) to be fixed even though the copy is temporary because it is "sufficiently permanent or stable to permit it to be perceived, reproduced, or otherwise communicated for a period of more than transitory duration." 190 As applied to newly developed DVR technology, the Second Circuit distinguished the RAM scenario from a DVR system that temporary holds 1.2 seconds of data in a buffer: "[U]nlike the data in cases like [the Ninth Circuit decision], which remained embodied in the computer's ... memory until the user turned the computer off, each bit of data here is rapidly and automatically overwritten as soon as it is processed." 191 While the court does acknowledge that the inquiry is fact specific, it concludes that "these facts strongly suggest that the works in this case are embodied in the buffer for only a 'transitory' period, thus failing the duration requirement" necessary for fixation. ${ }^{192}$

The Restatement usefully and properly draws on the statute and this and other case law interpreting it to clarify the fixation requirement, which was meant to adapt over time to new technologies. It quotes from the statute in $\S 8$ and uses Comments to the Section to explain how courts have understood the statutory language. For example, it specifies that paper books, electronic books, and USB flash drives are all requisite "tangible medi[a] of expression," even though the latter two did not exist when the 1976 Act was enacted. ${ }^{193}$ It summarizes the "more than transitory duration" element as not establishing a bright line for fixation's temporal requirement, but it also affirms both the Ninth and Second Circuit holdings (that 1.2 seconds in a buffer is not sufficient for fixation, but a computer remaining booted up for several minutes after loading a program into memory is sufficient for fixation). ${ }^{194}$ The Restatement helpfully illuminates that " $[t]$ he holdings in the leading cases and the legislative history suggest that fixation requires an embodiment that lasts long

\footnotetext{
187. Williams Elecs., Inc. v. Artic Int'l, Inc., 685 F.2d 870, 874 (3d Cir. 1982).

188. Id. (quoting Stern Elecs., Inc. v. Kaufman, 669 F.2d 852, 856 (2d Cir. 1982) (internal quotation marks omitted)).

189. Id.

190. MAI Sys. Corp. v. Peak Comput., Inc., 991 F.2d 511, 517-18 (9th Cir. 1993) (quoting 17 U.S.C. $\S 101)$.

191. Cartoon Network LLLP v. CSC Holdings, Inc., 536 F.3d 121, 129-30 (2d Cir. 2008).

192. Id.

193. Restatement Tentative Draft No. 1 (2020) $\S 8 \mathrm{cmt}$. b, at 74-75.

194. Id. $\S 8 \mathrm{cmts}$. $\mathrm{d}$, g, at $74-78,81-82$.
} 
enough to allow the enjoyment or exploitation of the work's expressive content after the embodiment is initially made."195

Congress signaled through its articulation of the fixation requirement that it wanted courts to interpret and apply the elaborate statutory language even to new technologies not yet developed, and it did not plan to revise this language even upon emergence of new technologies. As such, the Restatement usefully collects judicial interpretations of the statutory language both for existing and since-developed technologies and makes sense of the various fixation opinions in terms of audience enjoyment or exploitation.

\section{Categories of Copyrightable Subject Matter}

Retelling copyright law in a Restatement also benefits our understanding of the categories of copyrightable subject matter. The 1976 Act delineates the extent of copyrightable subject matter broadly and generally with a non-exhaustive list referencing illustrative, indeed prototypical, categories of copyrightable subject matter. The Restatement helpfully illuminates this subtle framework for copyrightable subject matter, analyzes why courts have not exploited it to the extent that they otherwise might, and highlights categories of copyrightable subject matter that might be less obvious to courts, lawyers, and others.

Until the 1909 Act, each successive copyright statute enumerated a closed list of categories of copyrightable subject matter. The first U.S. copyright statute, in 1790, provided protection only to maps, charts, and books. ${ }^{196}$ Over time, Congress repeatedly expanded the categories of copyrightable subject matter, by adding new types of works that could qualify for protection: engravings, etchings, and prints in $1802^{197}$; musical compositions in 1831 ${ }^{198}$; dramatic compositions in $1856^{199}$; photographs in $1865^{200}$; and paintings, drawings, and statues in $1870 .^{201}$ The 1909 Act moved away from limiting copyright protection to an enumerated list by granting protection to "all the writings of an author." 202 The Act further noted that an enumerated list in the statute for the purpose of administrative categorization of registration applications "shall not be held to limit the subject-matter of copyright." 203 Nonetheless, courts and the Copyright Office read the scope of copyrightable subject matter as being coextensive with the enumerated categories

\footnotetext{
195. Id. $\S 8 \mathrm{cmt} . \mathrm{d}$, at 77 .

196. Act of May 31, 1790, ch. 15, § 1, 1 Stat. 124, 124 (1790).

197. Act of Apr. 29, 1802, ch. 36, § 2, 2 Stat. 171, 171 (1802).

198. Act of Feb. 3, 1831, ch. 16, § 1, 4 Stat. 436, 436 (1831).

199. Act of Aug. 18, 1856, ch. 169, § 1, 11 Stat. 138, 139 (1856).

200. Act of Mar. 3, 1865, ch. 126, § 1, 13 Stat. 540, 540 (1865).

201. Act of July 8,1870 , ch. $230, \S 86,16$ Stat. $198,212(1870)$.

202. Copyright Act of Mar. 4, 1909, ch. 320, § 4, 35 Stat. 1075, 1076 (1909).

203. Id. $\S 5$. The enumerated list contained books, periodicals, lectures, sermons, addresses, dramatic or dramatico-musical compositions, musical compositions, maps, works of art, reproductions of a work of art, drawings or plastic works of a scientific or technical character, photographs, prints, and pictorial illustrations. Id. Congress added motion-picture photoplays and motion pictures other than photoplays to this list in 1912, Act of Aug. 24, 1912, ch. 356, 37 Stat. 488, 488 (1912), and sound recordings in 1971, Pub. L. No. 92-140, 85 Stat. 391 (1971).
} 
and declined to extend protection to other works, including sound recordings and choreographic works. ${ }^{204}$

Even though it might have seemed natural to read the 1909 Act's treatment of copyrightable subject matter expansively, it was the 1976 Act that was first understood to extend copyright protection broadly beyond a list of categories of subject matter. As discussed above, the 1976 Act extends copyright protection to fixed, original "works of authorship." 205 The Act elaborates that "[w]orks of authorship include the following categories: (1) literary works; (2) musical works, including any accompanying words; (3) dramatic works, including any accompanying music; (4) pantomimes and choreographic works; (5) pictorial, graphic, and sculptural works; (6) motion pictures and other audiovisual works; and (7) sound recordings." ${ }^{206}$ The Architectural Works Copyright Protection Act of 1990 later added "architectural works" to this list. ${ }^{207}$

Congress was cognizant of the meaning of the word "include" preceding the list of the seven categories of "works of authorship" in the 1976 Act. The legislative history explained that "[t]he use of the word 'include' ... makes clear that the listing is illustrative and not limitative, and that the seven categories do not necessarily exhaust the scope of 'original works of authorship' that the bill is intended to protect." ${ }^{208}$ In fact, a previous congressional study suggested that the use of broader statutory language for the first time in the 1909 Act "indicated a legislative desire to escape from rigorous adherence to the objects specifically enumerated in the statute." ${ }^{209}$ Congress did not want to have to legislatively add to the categories of copyrightable subject matter as it had multiple times since 1790. It sought to create a capacious sense of copyrightable subject matter by providing protection broadly to "works of authorship,",210 while also explaining the prototypical and indisputable

204. Capitol Records v. Mercury Records Corp., 221 F.2d 657, 661 (2d Cir. 1955) (sound recordings); Regulations of the Copyright Office, 21 Fed. Reg. 6021 (Aug. 11, 1956); Borge Varmer, Copyright in Choreographic Works (Study No. 28), in STAFF OF S. COMM. ON THE JUdiCIARY, 86TH

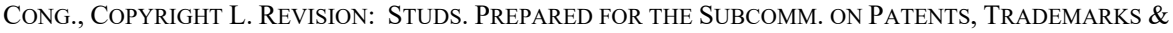
Copyrights OF THE COMM. ON THE Judiciary, Studies 26-28, at 94-96 (Comm. Print 1961) (choreographic works); STAFF OF N.Y.U. L. REV., The Meaning of "Writings" in the Copyright Clause of the Constitution (Study No. 3), in StAFF OF S. COMm. ON THE JudiCiary, 86Th Cong., Copyright L. Revision: Studs. Prepared For the Subcomm. on Patents, Trademarks \& COPYRights of THE COMM. ON the Judiciary, Studies 1-4, at 74-76 (Comm. Print 1960) [hereinafter N.Y.U. L. Rev., Meaning of "Writings"].

205. 17 U.S.C. § 102(a); supra Part III.B.

206. 17 U.S.C. $\$ 102$ (a) (emphasis added).

207. Pub. L. No. 105-304, 112 Stat. 2860 (1998) (codified as amended throughout 17 U.S.C.).

208. H.R. REP. NO. 94-1476, at 53 (1976); S. REP. NO. 94-473, at 52 (1975).

209. N.Y.U. L. REV., Meaning of "Writings", supra note 204, at 74. That said, the study went on to observe that "it seems that anything outside the [enumerations] of [the 1909 Act] has little chances for registration." Id. at 75. Moreover, the study cast doubt on this restrictive interpretation of the 1909 Act, in part because Theodore Roosevelt, in his 1905 address to Congress, "when speaking of the need to revise the copyright laws, part of his description was "they omit provision for many articles which, under modern reproductive processes, are entitled to protection." Id.

210. Despite the breadth of copyrightable subject matter, not all subject matter is copyrightable as a work of authorship. As set out in the legislative history, "there are unquestionably other areas of existing subject matter that this bill does not propose to protect but that future Congresses may want to." H.R. REP. NO. 94-1476, at 52 (1976); S. REP. NO. 94-473, at 51 (1975). 
categories of copyrightable subject matter by listing them as protected subcategories. ${ }^{211}$ As the legislative history explains, Congress set out to list as these illustrative categories "the general area of copyrightable subject matter, but with sufficient flexibility to free the courts from rigid or outmoded concepts of the scope of particular categories." 212

Congress recognized the need for the statute to adapt to creative practices, reporting that "[a]uthors are continually finding new ways of expressing themselves, but it is impossible to foresee the forms that these new expressive methods will take." 213 Indeed, since that statement in the mid-1970s, digital books, blogs, internetstreamed videos, and social media posts are only a few new expressive methods that have arisen. Congress expressed an intent to avoid revising the copyright statute each time such expressive methods emerged: "The bill does not intend either to freeze the scope of copyrightable technology or to allow unlimited expansion into areas completely outside the present congressional intent." ${ }^{214}$ It sought to elaborate copyrightable subject matter so that "neither . . . that subject matter is unlimited nor that new forms of expression within that general area of subject matter would necessarily be unprotected." 215

The Restatement elucidates this subtle structure by quoting the statutory language in $\S 2$ and then explaining further how courts have ruled on expansive claims of copyrightable subject matter. In particular, $\S 2$ 's Comments indicate that although Congress undoubtedly authorized courts to locate copyrightable subject matter beyond the illustrative enumerated categories, "[n]o court to date has recognized as copyrightable any material that falls entirely outside all of the enumerated categories." 216 This surprising doctrinal development might be explained in several

211. Cf. Jeanne C. Fromer, Claiming Intellectual Property, 76 U. CHI. L. REV. 719, 739-40 (2009) (explaining how more specific dependent claims in patent law "have a 'central claim'-like communicative effect of highlighting prototypes of the associated [and broader] independent claim").

212. H.R. REP. NO. 94-1476, at 53; S. REP. NO. 94-473, at 52. One scholar has argued against this approach. R. Anthony Reese, Copyrightable Subject Matter in the 'Next Great Copyright Act', 29 BERKELEY TECH. L.J. 1489, 1502 (2014) ("Congress is the appropriate and best-positioned actor to determine what should and should not be protected by copyright, both because the scope of copyrightable subject matter is a policy question best answered by the elected legislature and because Congress is better equipped to appropriately tailor any protection it decides to grant."). Another has argued that there are principles courts and others can use to deem matter beyond the enumerated categories as protectable works of authorship. Pamela Samuelson, Evolving Conceptions of Copyright Subject Matter, 78 U. PITT. L. REV. 17 (2016).

213. H.R. REP. NO. 94-1476, at 51; S. REP. NO. 94-473, at 51.

214. H.R. REP. NO. 94-1476, at 51; S. REP. No. 94-473, at 51. Even so, the Copyright Office has refused to register claims of copyright for matters that do not lie within one of Congress's illustrative categories of subject matter. Registration of Claims To Copyright, 77 Fed. Reg. 37,605, 37,607 (Jun. 22, 2012).

215. H.R. REP. No. 94-1476, at 51; S. REP. No. 94-473, at 51. Nonetheless, Congress recognized that future Congresses might decide to change the bounds of copyrightable subject matter. H.R. REP. NO. 94-1476, at 52; S. REP. NO. 94-473, at 51.

216. Restatement Tentative Draft No. 1 (2020) $\S 2 \mathrm{cmt}$. c, at 11 (giving basketball games and parades as examples of judicially rejected expansions of subject matter) (citing, in the Reporters' Notes, Nat'1 Basketball Ass'n v. Motorola, Inc., 105 F.3d 841, 846 (2d Cir. 1997) (reasoning that the enumerated "list does not include athletic events, and, although the list is concededly non-exclusive, such events are neither similar nor analogous to any of the listed categories"); Prod. Contractors, Inc. v. WGN Cont'1 
ways. Perhaps courts have not yet found fixed and original works of authorship outside of the broad illustrative categories that Congress established. Or perhaps courts lack a clear method to determine whether a new subject matter category ought to qualify. Alternatively, maybe courts mistakenly believe they cannot protect under copyright law any matter outside of the illustrative categories listed in the Act. The Restatement's Comments include this analysis and diagnose courts' unwillingness to expand subject matter beyond the illustrative categories as due to "[t]he breadth of the definitions of the statute's enumerated categories of works of authorship, the paucity of congressional guidance on recognizing other categories of works of authorship, and the approach that courts and the Copyright Office have taken to claims of copyright in material falling outside all of the enumerated categories."217

By providing this empirical information together with an analysis of it, the Restatement helps courts decide whether and when to extend subject matter beyond the illustrative categories. Should a future court think other courts unduly restricted application of the categories of copyrightable subject matter to the enumerated statutory list, it might rule that a new category is justified under suitable circumstances. If a court believes that it lacks guidance on the question of adding to the subject matter categories, it might conclude that a "presumption against copyright protection for material that falls outside of the statute's enumerated categories" has not been overcome and deem the capacious enumerated categories sufficient on which to rest its decision. ${ }^{218}$ Either way, the Restatement gives courts a helpful analytical framework to approach copyrightable subject matter by retelling the statutory provisions in the context of rendered decisions on the categories of copyrightable subject matter over the past several decades.

Two other reasons make the Restatement's attention to categories of copyrightable subject matter critical for the clarification of copyright law. First, the category of copyrightable subject matter into which a work is placed can affect the work's scope of protection as well as the fact of protection. ${ }^{219}$ Second, the categories are not intuitive to non-experts and thus their further explanation in the Restatement is helpful. For example, $\S 2$ sets out that "[c]omputer programs are protectable under the Copyright Act as a type of literary work." 220 Although a "literary work" might seem to encompass only books and periodicals, for example, it is in fact defined as a work (other than an audiovisual work) "expressed in words, numbers, or other verbal or numerical symbols or indicia." 221 The Restatement's Comments explain that software programs fit literally within this category, that Congress intended to protect

Broad. Co., 622 F. Supp. 1500, 1502-04 (N.D. Ill. 1985) (reasoning that a parade is not a "work of authorship")).

217. Restatement Tentative Draft No. 1 (2020) § 2 cmt. c, at 11.

218. Id.

219. See, e.g., 17 U.S.C. § 113(c) (stating that the scope of exclusive rights in pictorial, graphic, and sculptural works does not extend to their lawful reproduction in useful articles that are offered for sale or other distribution to the public in connection with advertisements).

220. Restatement Tentative Draft No. 1 (2020) § 2(b), at 9.

221. 17 U.S.C. $\S 101$ 
them under this category, and that courts have followed this view. ${ }^{222}$ By contrast, there is no definition of "musical works" in the Act, and Restatement commentary usefully explains that although "no court decision offers a comprehensive interpretation of the term, ... various decisions have identified melody, rhythm, harmony, and tempo as among the elements of a musical work other than lyrics." 223 The Restatement similarly summarizes the definitions or relevant aspects of the other categories, as courts have understood them. ${ }^{224}$

By traversing courts' interpretations of what constitutes copyrightable subject matter, the Restatement helpfully sheds light on the subtle statutory framework, how and why courts have not exploited the extent of this framework, and how to understand and apply the enumerated categories of subject matter should new forms of expression arise in the future.

\section{E. IDEA-EXPRESSION DISTINCTION}

The "idea-expression distinction" in copyright law is fundamental to the law's structure and the subject of ongoing controversy especially in the digital age. ${ }^{225}$ The idea-expression distinction is shorthand for various matter-including but not limited to ideas - that lies outside the scope of copyright, as compared with expression, which is protectable if it is a fixed and original work of authorship. Specifically, the Copyright Act of 1976 excludes certain subject matter from copyright protection: "In no case does copyright protection for an original work of authorship extend to any idea, procedure, process, system, method of operation, concept, principle, or discovery, regardless of the form in which it is described, explained, illustrated, or embodied in such work." 226 As the statutory language attests, unprotected matter extends to subject matter beyond ideas. ${ }^{227}$ The Restatement breaks down what appears as a singular statutory rule into subcategories, each with its own distinct analysis as understood by courts. At a time when this statutory provision is subject to increasing attention, the Restatement's clarification and analysis of the case law will advance copyright practice.

222. Restatement Tentative Draft No. 1 (2020) § 2 cmt. d, at 11-12 (quoting H.R. REP. No. 94-1476, at 54 (1976) (writing that the category of literary works "includes computer data bases, and computer programs to the extent that they incorporate authorship in the programmer's expression of original ideas, as distinguished from the ideas themselves")).

223. Id. $\S 2 \mathrm{cmt}$. e, at 12 (citing, in the Reporters' Notes, Newton v. Diamond, 204 F. Supp. 2d 1244, 1249 (C.D. Cal. 2002), aff'd, 388 F.3d 1189 (9th Cir. 2004); Pamfiloff v. Giant Records, Inc., 794 F. Supp. 933, 938 (N.D. Cal. 1992); Ellis v. Diffie, 177 F.3d 503, 506 (6th Cir. 1999)).

224. Id. $\S 2 \mathrm{cmts}$. $\mathrm{f}-\mathrm{j}, 1$, at 13-19 (dramatic works, pantomimes and choreographic works, pictorial, graphic and sculptural works, motion pictures and other audiovisual works, sound recordings, and architectural works).

225. Google LLC v. Oracle Am. Inc., No. 18-956 (argued Oct. 7, 2020), currently pending before the U.S. Supreme Court, is an example of the centrality of this distinction to copyright law and of its contested status.

226. 17 U.S.C. $\S 102(b)$.

227. See 1 Paul Goldstein, Goldstein On Copyright $§ 2.3 .1$ (2020); Pamela Samuelson, Why Copyright Law Excludes Systems and Processes from the Scope of Its Protection, 85 TEX. L. REv. 1921, 1921-23 (2007). 
The meaning of $\S 102(\mathrm{~b})$ requires application of case law as well as close attention to the enumerated list of categories it contains. It is therefore a statutory provision whose interpretation demands a combination of interpretive processes described above. ${ }^{228}$ As with Congress's view of its encoded originality requirement in the 1976 Act, legislative history makes clear that $\S 102$ (b) "in no way enlarges or contracts the scope of copyright protection under the present law." ${ }^{229}$ Both House and Senate reports elaborate that "[i]ts purpose is to restate, in the context of the new ... Federal system of copyright, that the basic dichotomy between expression and idea remains unchanged." ${ }^{230}$ Like the originality requirement, this rule is thus well-suited to being retold in the Restatement of Copyright through an analysis of the case law over time..$^{231}$

The Restatement also advances the clarification of copyright law because the "idea-expression distinction" moniker masks at least three longstanding commonlaw “__ - expression” distinctions that have been clarified over time. ${ }^{232}$ First, a process-expression distinction extends to the statutory categories of procedure, process, system, and method of operation. Second, an idea-expression distinction covers the statutory categories of idea, concept, and principle. Third, a factexpression distinction exists but is harder to identify literally in the statute's language other than with the word "discovery." These subcategories arise from the enumerated list and guide the application of this critical statutory provision. The Restatement's treatment of this section provides welcome assistance for this complex but important task.

Though they overlap, the principal policies underlying each subcategory are somewhat distinct. ${ }^{233}$ Processes are excluded from the scope of copyright protection because, as the Supreme Court held in 1879 in Baker v. Selden, "[ $t]$ hat is the province of []patent, not of copyright." ${ }^{, 234}$ For a patent to issue, the Patent Office must scrutinize the invention claimed in the application for novelty, nonobviousness, and other strict requirements. Copyrighted material undergoes no such scrutiny or examination. ${ }^{235}$ As Paul Goldstein explains, "[d]octrinally, the presence of patent law's rigorous standards cautions courts in copyright infringement cases not to allow copyright, with its notably lax standards, to protect functional elements of copyrighted works." 236 Ideas are understood differently. As the Supreme Court has explained, ideas are excluded from the scope of copyright protection so that they can

228. See supra Part III.B-C.

229. H.R. REP. NO. 94-1476, at 57 (1976); S. REP. NO. 94-473, at 54 (1975).

230. H.R. REP. NO. 94-1476, at 57 (emphasis added); S. REP. No. 94-473, at 54 (emphasis added).

231. See supra Part III.B.

232. Jeanne C. Fromer \& Christopher Jon Sprigman, Copyright LaW: CASES AND MATERIALS 59 (2d version 2020); cf. Pamela Samuelson, Reconceptualizing Copyright's Merger Doctrine, 63 J. COPYRIGHT SOC'Y OF U.S.A. 417, 438-39 (2016) (identifying at least six distinctions with expression in the context of merger doctrine, including idea-expression, fact-expression, law-expression, process-expression, and system-expression).

233. FROMER \& SPRIGMAN, supra note 232, at 59.

234. 101 U.S. 99, $102(1879)$.

235. Id.

236. Paul Goldstein, Infringement of Copyright in Computer Programs, 47 U. PITT. L. REV. 1119, 1130 (1986). 
be left free for all to use as building blocks to create further expression. ${ }^{237}$ Courts attribute this principle to protecting First Amendment values. ${ }^{238}$ Courts explain the exclusion of facts from copyright protection on the ground that they too provide the building blocks for all expression, but facts also lack originality because they are not independently created by an author. ${ }^{239}$ Court cases have applied rules for each of these distinctions in light of their underlying purposes. ${ }^{240}$ The Restatement's summary and analysis of each exclusion as courts have described them will aid the development of law, especially regarding information goods and technology, which are critical areas in dispute today.

In particular, $\S 12$ of the Restatement repeats the statute's statement that copyright protection extends to expression but "does not 'extend to any idea, procedure, process, system, method of operation, concept, principle, or discovery, regardless of the form in which it is described, explained, illustrated, or embodied in such work." "241 Section 12 further explains that copyright protection "does not extend to any fact regardless of the form in which it is described, explained, illustrated, or embodied in such work." 242 Section 14 specifically addresses the exclusion of ideas from the scope of copyright protection: "The scope of copyright protection for a work of authorship does not 'extend to any idea,' 'concept,' or 'principle,' 'regardless of the form in which it is described, explained, illustrated, or embodied in such work." ${ }^{243}$ Section 15, which has not yet been released for membership approval, will address separately the exclusion of methods from the scope of copyright protection, whereas $\S 16$, which has also not yet been released, will address the exclusion of facts from the scope of copyright protection. ${ }^{244}$ As the Comments explain, the Restatement sorts and groups these items into three categories rather than deal with the idea-expression distinction monolithically because

[i]n light of the plain language of [the statute], the word "idea" [in this context] is best understood to operate as shorthand for those elements of a work that by their nature are not protected by copyright on the basis of underlying policy concerns recognized by Congress in [the statute] and in judicial decisions interpreting the scope of copyright protection. ${ }^{245}$

\footnotetext{
237. Feist Publ'ns, Inc. v. Rural Tel. Serv. Co., 499 U.S. 340, 349-50 (1991).

238. Harper \& Row Publishers, Inc. v. Nation Enters., 471 U.S. 539, 556 (1985).

239. See id; Feist, 499 U.S. at 347.

240. For cases that discuss the process-expression distinction, see Lotus Dev. Corp. v. Borland Int'l, Inc., 49 F.3d 807 (1st Cir. 1995), and Bikram's Yoga Coll. of Ind., LP v. Evolation Yoga, LLC, 803 F.3d 1032 (9th Cir. 2015). For cases that discuss the idea-expression distinction, see Erickson v. Blake, 839 F. Supp. 2d 1132 (D. Ore. 2012) and Mannion v. Coors Brewing Co., 377 F. Supp. $2 d 444$ (S.D.N.Y. 2005). For a case expounding on the fact-expression distinction, see Hoehling v. Univ. City Studios, Inc., 618 F.2d 972 (2d Cir. 1980).

241. Restatement Tentative Draft No. 1 (2020) § 12(a)-(b), at 115 (quoting 17 U.S.C. § 102(b)).

242. Id. $\S 12(\mathrm{~b})(2)$, at 115 . It then continues that "[ $\mathrm{t}]$ hese elements to which the scope of copyright protection does not extend are categorized and discussed in $\S 14$ to $16 . "$ Id. $\S 12(\mathrm{~b})$, at 115.

243. Id. § 14, at 129 .

244. Id. § $12 \mathrm{cmt}$. e, at 120 .

245. Id. $\S 12 \mathrm{cmt}$. b, at 117 .
} 
Furthermore, the Restatement elaborates that " $[\mathrm{g}]$ rouping the statutorily identified unprotectable elements of a work of authorship into these three categories [of ideas, methods, and facts] assists in understanding the rationales for, and applications of, the exclusion with respect to different types of unprotectable elements." 246

Although we cannot yet analyze $\S \S 15$ and 16, the Restatement's disaggregation of the idea-expression distinction in $\S \S 13$ and 14 is illustrative. To elucidate the distinction between expression and other types of matter, $\S 13$ explains that "[t]he scope of copyright protection for 'original works of authorship fixed in any tangible medium of expression' extends to expression in a work that is original to the work's author or authors. ${ }^{247}$ By contrast, $\S 14$ sets out a major category of matter excluded from the scope of copyright protection: ideas, concepts, and principles, as noted above. ${ }^{248}$ A Comment to the Section explains that ideas are excluded from copyright protection "to ensure that copyright protection will not inhibit others from employing basic intellectual building blocks or from exploring existing ideas using their own expression. To encourage authors to create expressive works, copyright must allow all authors to use building blocks basic to each medium of expression." ${ }^{249}$ The Comments proceed to explain how courts have distinguished unprotected ideas from protectable expression by using a levels-of-abstraction analysis. ${ }^{250}$ Because, as the Restatement notes, courts apply this as a "loose standard" instead of a precise rule, the Restatement analysis provides a framework that courts may consider when classifying an aspect of a work as idea or expression: "[T]he focus should be on the purposes that animate the exclusion - namely, appropriately limiting the scope of the copyright owner's exclusive rights such that subsequent creators are not prevented from reusing basic intellectual building blocks or from exploring existing ideas using their own expression." ${ }^{251}$ The reasons for excluding ideas from the scope of copyright protection may be distinct from those for excluding processes and facts, something that might not be apparent when they are all lumped together without analytical structure in the statute in $\S 102(\mathrm{~b})$. The Restatement helpfully systematizes the various categorical exclusions, explains why ideas are unprotected, and describes how that affects an analysis of categorizing material as idea or expression.

\section{F. AUTHORSHIP AND OWNERSHIP}

A final illustration of how the Restatement helpfully illuminates copyright law is with regard to copyright's provisions on authorship and ownership. These provisions rely on common law in other areas, particularly contract, property, and agency. As

\footnotetext{
246. Id. $\S 12 \mathrm{cmt}$. e, at 120 .

247. Id. § 13, at 125 (quoting 17 U.S.C. § 102(a)).

248. Id. § 14, at 129 (quoting 17 U.S.C. $\$ 102(\mathrm{~b})$ ).

249. Id. \& $14 \mathrm{cmt}$. b, at 129 .

250. Id. § $14 \mathrm{cmt}$. d, at 130 (citing Nichols v. Univ. Pics. Corp., 45 F.2d 119 (2d Cir. 1930)).

251. Id. § $14 \mathrm{cmt} \mathrm{d,} \mathrm{at} 131$ (citing Feist Publ'ns., Inc. v. Rural Tel. Serv. Co., 499 U.S. 340 (1991); Country Kids 'N City Slicks, Inc. v. Sheen, 77 F.3d 1280 (10th Cir. 1996)).
} 
such, the Restatement elaborates these provisions by integrating these other areas of common law when relevant to illuminate copyright law on authorship and ownership.

The copyright statute provides that "[c]opyright in a work protected under this title vests initially in the author or authors of the work. The authors of a joint work are coowners of copyright in the work." 252 A "joint work" is statutorily defined as "a work prepared by two or more authors with the intention that their contributions be merged into inseparable or interdependent parts of a unitary whole." ${ }^{253}$ The rule is different for a "work made for hire," statutorily defined as either "a work prepared by an employee within the scope of his or her employment" or "a work specially ordered or commissioned for use as [one of a number of enumerated categories of works, including motion picture or test], if the parties expressly agree in a written instrument signed by them that the work shall be considered a work made for hire." 254 For a work made for hire, "the employer or other person for whom the work was prepared is considered the author ... and, unless the parties have expressly agreed otherwise in a written instrument signed by them, owns all of the rights comprised in the copyright." 255

The statute also provides that these rights can be transferred: "The ownership of a copyright may be transferred in whole or in part by any means of conveyance or by operation of law, and may be bequeathed by will or pass as personal property by the applicable laws of intestate succession." ${ }^{256}$ The statute explains further that a transfer of copyright ownership is "an assignment, mortgage, exclusive license, or any other conveyance, alienation, or hypothecation of a copyright or of any of the exclusive rights comprised in a copyright, whether or not it is limited in time or place of effect, but not including a nonexclusive license." ${ }^{257}$ The statute specifies that for such a transfer to be effective, other than if it is by operation of law, there must be "an instrument of conveyance, or a note or memorandum of the transfer ... in writing and signed by the owner of the rights conveyed or such owner's duly authorized agent." 258

These provisions depend in substantial part on other areas of the common law, especially contract, property, and agency laws, and courts have interpreted these statutory provisions on authorship and ownership in light of those areas of the law. For example, the Supreme Court has understood the statutory provisions on works made for hire as Congress codifying the common law of agency. In seeking to understand when a work was prepared by "an employee within the scope of his or her employment," as the statute requires, the Supreme Court explained: "The Act nowhere defines the terms 'employee' or 'scope of employment.' It is, however, well established that '[w]here Congress uses terms that have accumulated settled meaning under ... common law, a court must infer, unless the statute otherwise

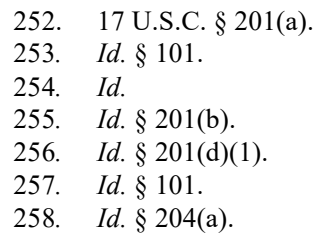


dictates, that Congress means to incorporate the established meaning of these terms." 259 The Court concluded that the statute suggests "Congress' intent to incorporate the agency law definition" of "employee" into the copyright statute. ${ }^{260}$ Citing the Restatement of Agency, the Court then elaborated the thirteen factors that must be considered to determine whether a work is created by an employee, including "the source of instrumentalities and tools" and "the provision of employee benefits." 261 Other federal courts have similarly interpreted the requirement that the work done be in the "scope of employment" to be adjudged by common-law agency principles. $^{262}$

Also consider the law of joint works, which relies not on agency law but property law. As Congress explained in the legislative history to the 1976 Act, " $[\mathrm{t}]$ here is ... no need for a specific statutory provision concerning the rights and duties of the coowners of a work; court-made law on this point is left undisturbed."263 The legislative history further specified that "[u]nder the bill, as under the present law, co-owners of a copyright would be treated generally as tenants in common."264 From this legislative direction, courts have relied on the common law of property to grant co-authors of a joint work an undivided fractional interest in the work. ${ }^{265}$

These statutory provisions also rely heavily on the common law of contracting to define rights with regard to joint works, works made for hire, and transfers of ownership. For example, courts refer to contracts when assessing whether the putative co-authors intended a work to be a "joint work." The Ninth Circuit has specifically held that " $[\mathrm{t}]$ he best objective manifestation of a shared intent . . is a contract saying that the parties intend to be or not to be co-authors." ${ }^{266}$ Additionally, for a work to be made for hire by an independent contractor, "the parties [must] expressly agree in a written instrument signed by them that the work shall be considered a work made for hire." 267 And a work that otherwise would constitute a work made for hire may instead be owned by the employee if "the parties have expressly agreed otherwise in a written instrument signed by them."268 Finally, the

259. Cmty. for Creative Non-Violence v. Reid, 490 U.S. 730, 739 (1989) (quoting NLRB v. Amax Coal Co., 453 U.S. 322, 329 (1981)).

260. Id. at 740 .

261. Id. at 751-52 (notes omitted; citing Restatement (SECOND) OF AGENCY § 220(2)). The full list of factors is "the hiring party's right to control the manner and means by which the product is accomplished"; "the skill required; the source of the instrumentalities and tools; the location of the work; the duration of the relationship between the parties; whether the hiring party has the right to assign additional projects to the hired party; the extent of the hired party's discretion over when and how long to work; the method of payment; the hired party's role in hiring and paying assistants; whether the work is part of the regular business of the hiring party; whether the hiring party is in business; the provision of employee benefits; and the tax treatment of the hired party." Id.

262. E.g., Avtec Sys. v. Peiffer, 21 F.3d 568, 571 (4th Cir. 1994) (citing Restatement (SeCOND) OF AGENCY $§ 228$ ).

263. H.R. REP. NO. 94-1476, at 121 (1976); S. REP. NO. 94-473, at 106 (1975).

264. H.R. REP. NO. 94-1476, at 121 (1976); S. REP. NO. 94-473, at 106 (1975).

265. E.g., Childress v. Taylor, 945 F.2d 500, 508 (2d Cir. 1991); Pye v. Mitchell, 574 F.2d 476, 480 (9th Cir. 1978).

266. Aalmuhammed v. Lee, 202 F.3d 1227, 1235 (9th Cir. 2000).

267. 17 U.S.C. § 101

268. Id. §201(b). 
statute requires "an instrument of conveyance, or a note or memorandum of the transfer ... in writing and signed by the owner of the rights conveyed or such owner's duly authorized agent" for a transfer of ownership by voluntary conveyance. ${ }^{269}$ These requirements are similar to and draw on writing requirements in contract law, combining the common law of contracts with the 1976 Copyright Act for its proper application. ${ }^{270}$

The Restatement sheds light on how these other areas of common law-agency, contract, and property - interact with copyright's statutory provisions on authorship and ownership. The Restatement does so by including these other legal areas in its retelling of copyright law. For example, $\S 22$, which governs joint works, explains how contracts may be helpful, but not always dispositive, in assessing whether a work is co-authored. It states after quoting the statutory definition of a "joint work," that "[t]o have the requisite intent to be a co-author of a joint work, an author must intend, at the time the author creates that author's contribution to the work, that the contribution be merged into a joint work as a unitary whole." ${ }^{271}$ A Comment to $\S 22$ elaborates that "[e]xpress statements of intent-for example, in a contract between co-authors - are strong evidence that the parties making the statements possessed the requisite intent." 272 Another Comment emphasizes the helpfulness of contracting by providing that

an express agreement among the contributors that a particular contributor will be listed as a co-author of the work would offer evidence to support a finding that the contributions made by that particular contributor were sufficient to qualify the contributor as a joint author; contributors are generally unlikely (absent a contrary industry custom) to agree to list as a co-author a contributor who does not make what they regard as an authorial contribution to the work as a whole. ${ }^{273}$

The Restatement Comments also recognize, however, that a contract directed to coauthorship may not be definitive: "[A] contract in which parties agree to be coauthors of a work cannot make someone a co-author of a joint work if the requirements discussed in this Section are not met." 274

Sections 22 and 23 elaborate the role of the common law of property in ownership of joint works. Section 22 provides that " $[t]$ he co-authors who create a joint work are the initial co-owners of the copyright in that joint work, as specified in $\S 23 .{ }^{.275}$ Section 23 further specifies that "[u]nless the co-authors of a joint work have agreed otherwise, each co-author owns an equal undivided fractional interest in the copyright in the entire joint work." ${ }^{276}$ Due to this ownership, $\S 23$ provides that any

269. Id. § 204(a).

270. Kongsberg Int'l Inc. v. Rice, 16 F.3d 355, 357 (9th Cir. 1994) (explaining that this "writing requirement not only protects authors from fraudulent claims" much like a statute of frauds, but it "also enhances predictability and certainty of ownership").

271. Restatement Tentative Draft No. 1 (2020) § 22(c), at 165.

272. Id. $\S 22 \mathrm{cmt}$. c, at 166 .

273. Id. $\S 22 \mathrm{cmt}$. e, at 173 .

274. Id. $\$ 22 \mathrm{cmt}$. f, at 173 .

275. Id. § 22(d), at 165 .

276. Id. § 23(a), at 187. 
co-author can exercise the rights of a copyright owner or authorize another to do so nonexclusively subject to a duty to account to the other co-owners or to transfer its fractional interest, but the co-owners unanimously can act together to authorize another to exercise exclusive copyright rights or to transfer the entire copyright. ${ }^{277}$

With regard to works made for hire, $\S 24$ of the Restatement explains the relevance of the common law of agency to the statute's interpretation: One way for a work to be made for hire is if it is " prepared by an employee within the scope of his or her employment' as determined under the general common law of agency."278 Comments to this Section explain how courts have used this common law of agency to determine whether someone is an employee acting within the scope of their employment. ${ }^{279}$ Section 24 also underscores the relevance of contracting, whether to transform a work created by an independent contractor into a work made for hire or to deem a work created by an employee within the scope of their employment not to be a work made for hire. ${ }^{280}$ The Comments elaborate on the content and timing of such agreements by describing many court decisions arising in diverse contexts and industries. ${ }^{281}$

Finally, with regard to transfers of copyright, $\S 25$ of the Restatement states that "[t]o be valid, transfers by voluntary conveyance ... must satisfy the written instrument requirement addressed in $\S 26 . " 282$ Section 26 expands on the written instrument requirement by quoting the statutory language governing transfers: "A transfer of copyright ownership by voluntary conveyance, as described in $\$ 25(b)(1)$, 'is not valid unless an instrument of conveyance, or a note or memorandum of the transfer, is in writing and signed by the owner of the rights conveyed or such owner's duly authorized agent." 283 The Section explains that "[t]his is known as the written instrument requirement." 284 The Restatement then helpfully explains the array of circumstances when the written instrument requirement does not apply: to "nonexclusive licenses" (because they are excluded from the statutory definition of transfers of copyright), ${ }^{285}$ transfers under the terms of a will or by intestate succession," 286 and "transfers by operation of law" (because they are not transfers by voluntary conveyance). ${ }^{287}$ The Restatement Comments disaggregate the written instrument requirement into three elements: "an instrument of conveyance, or a note or memorandum of the transfer"; "in writing"; and "signed by the owner of the rights conveyed or such owner's duly authorized agent." 288 The Comments summarize the case law and other statutes governing each of these elements, including that the

277. Id. § 23(b), at 187

278. Id. § 24(a)(1), at 208.

279. Id. § $24 \mathrm{cmts} . \mathrm{c}-\mathrm{d}$, at $209-15$.

280. Id. § 24(b)-(c), at 208.

281. Id. $\S 24 \mathrm{cmts}$. $\mathrm{g}-\mathrm{h}$, at 218-22.

282. Id. § 25(c), at 232 .

283. Id. § 26, at 249 (quoting 17 U.S.C. \$ 204(a)).

284. Id.

285. Id. § 26(b)(1), at 249.

286. Id. § 26(b)(2), at 249 .

287. Id. § 26(b)(3), at 249 .

288. Id. $\S 26 \mathrm{cmt}$. d, at 250 (citing 17 U.S.C. $\S 204(\mathrm{a})$ ). 
writing can have been prepared for another purpose and can have been signed electronically, ${ }^{289}$ and that courts have split on the legitimacy of a writing post-dating the agreement to transfer. ${ }^{290}$

The Restatement provides a robust retelling of copyright law by integrating the external common law of contract, agency, and property on which copyright's law of authorship and ownership relies. These aspects of copyright law are central to the law's operation in the creative and innovative industries, which have dramatically evolved since the 1976 passage of the Copyright Act. The Restatement's framework for and clarification of this complicated area of law will be a welcome resource for lawyers, judges, and students.

\section{CONCLUSION}

In conclusion, the Restatement of Copyright Law is a useful retelling of copyright law. This Restatement project fits well within the ALI's mandate. ${ }^{291}$ The act of restating in the manner that is the ALI's signature form is also consistent with the legal practice, which inevitably involves acts of legal exposition and interpretation, even for statutory law. ${ }^{292}$ The copyright statute draws on longstanding common law, gestures to courts to continue developing this common law to interpret the statute, and is a statute for the ages. Judges and lawyers - whatever their views on copyright policy - should embrace this carefully crafted Restatement draft on originality, fixation, categories of copyrightable subject matter, the idea-expression distinction, and authorship and ownership, to guide legal practice and decision-making in copyright law. ${ }^{293}$

289. Id. $\$ 26 \mathrm{cmt}$. e, at 250-51; id. § $26 \mathrm{cmt}$ g, at 251-52 (citing 15 U.S.C. $\$ 7001$ (a)(1)).

290. Id. $\$ 26 \mathrm{cmt}$. i, at 253-55 (citing, inter alia, Konigsberg Int’1 Inc. v. Rice, 16 F.3d 355 (9th Cir. 1994); Barefoot Architect, Inc. v. Bunge, 632 F.3d 822 (3d Cir. 2011)).

291. See supra Part I.

292. See supra Part II.

293. See supra Part III. 